\title{
Expressions of climate perturbations in western Ugandan crater lake sediment records during the last 1000 years
}

\author{
K. Mills ${ }^{1,2, *}$, D. B. Ryves ${ }^{1}$, N. J. Anderson ${ }^{1}$, C. L. Bryant ${ }^{3}$, and J. J. Tyler ${ }^{4}$ \\ ${ }^{1}$ Department of Geography, Loughborough University, Loughborough, Leics LE11 3TU, UK \\ ${ }^{2}$ School of Science and Engineering, University of Ballarat, Ballarat, Vic 3350, Australia \\ ${ }^{3}$ NERC Radiocarbon Facility, Scottish Enterprise Technology Park, East Kilbride, Scotland G75 0QF, UK \\ ${ }^{4}$ School of Earth and Environmental Sciences, University of Adelaide, Adelaide, SA 5001, Australia \\ * current address: British Geological Survey, Keyworth, Nottingham NG12 5GG, UK
}

Correspondence to: K. Mills (k.mills2@lboro.ac.uk)

Received: 15 August 2013 - Published in Clim. Past Discuss.: 10 September 2013

Revised: 26 June 2014 - Accepted: 3 July 2014 - Published: 27 August 2014

\begin{abstract}
Equatorial East Africa has a complex regional patchwork of climate regimes, sensitive to climate fluctuations over a variety of temporal and spatial scales during the late Holocene. Understanding how these changes are recorded in and interpreted from biological and geochemical proxies in lake sedimentary records remains a key challenge to answering fundamental questions regarding the nature, spatial extent and synchroneity of climatic changes seen in East African palaeo-records. Using a paired lake approach, where neighbouring lakes share the same geology, climate and landscape, it might be expected that the systems will respond similarly to external climate forcing. Sediment cores from two crater lakes in western Uganda spanning the last $\sim 1000$ years were examined to assess diatom community responses to late Holocene climate and environmental changes, and to test responses to multiple drivers using redundancy analysis (RDA). These archives provide annual to sub-decadal records of environmental change.

Lakes Nyamogusingiri and Kyasanduka appear to operate as independent systems in their recording of a similar hydrological response signal via distinct diatom records. However, whilst their fossil diatom records demonstrate an individualistic, indirect response to external (e.g. climatic) drivers, the inferred lake levels show similar overall trends and reflect the broader patterns observed in Uganda and across East Africa. The lakes appear to be sensitive to large-scale climatic perturbations, with evidence of a dry Medieval Climate Anomaly (MCA; ca. AD 1000-1200). The diatom record from Lake Nyamogusingiri suggests a drying climate during
\end{abstract}

the main phase of the Little Ice Age (LIA) (ca. AD 16001800), whereas the diatom response from the shallower Lake Kyasanduka is more complex (with groundwater likely playing a key role), and may be driven more by changes in silica and other nutrients, rather than by lake level. The sensitivity of these two Ugandan lakes to regional climate drivers breaks down in ca. AD 1800, when major changes in the ecosystems appear to be a response to increasing cultural impacts within the lake catchments, although both proxy records appear to respond to the drought recorded across East Africa in the mid-20th century.

The data highlight the complexity of diatom community responses to external drivers (climate or cultural), even in neighbouring, shallow freshwater lakes. This research also illustrates the importance of, and the need to move towards, a multi-lake, multi-proxy landscape approach to understanding regional hydrological change which will allow for rigorous testing of climate reconstructions, climate forcing and ecosystem response models.

\section{Introduction}

The climate of East Africa has exhibited high inter-decadal variability during the last 2000 years, whilst the short instrumental record is characterised by high magnitude and abrupt climatic events, most apparent in rainfall patterns (Nicholson, 1996, 2000; Nicholson and Yin, 2001; Conway, 2002). Previous studies within East Africa have shown that some of 
these past climatic events are synchronous across the region. However, a number of more recent studies have indicated spatial complexity and heterogeneity within the African tropics within the context of far-reaching palaeoclimate scenarios (e.g. the Little Ice Age; Russell et al., 2007; Verschuren et al., 2000; Ssemmanda et al., 2005; Stager et al., 2005; Ryves et al., 2011). Palaeoclimatic research in Africa is of immense importance, as it has the means to provide a historical and pre-colonial perspective of past environmental and/or climatic variability (caused by natural and anthropogenic factors). The last 1000 years is a crucial period in East African history, during which time there were major societal transformations and political changes, which have often been linked to fluctuations in climatic conditions (e.g. Taylor et al., 2000; Robertshaw and Taylor, 2000; Verschuren et al., 2000; Robertshaw et al., 2004; Doyle, 2006). This time frame is one of the most challenging in which to interpret regional climatic and environmental changes from East African lake sediment records, due to (1) problematic dating of sediments and (2) anthropogenic activity in catchments, especially agricultural (with the development of nucleated, permanent settlements) and the implementation of new technologies (e.g. iron technology and the associated forest clearance for the production of charcoal).

More recently, research has focused upon compiling continent-wide historical and proxy temperature records from a range of archives to understand variations in the climate of the last 2000 years (Nicholson et al., 2013). The records derived from lake sediments in equatorial East Africa imply a complex regional patchwork of responses to changes in climate during this period, highlighting the multiple interacting drivers that influence the response of biological and geochemical proxies through time. Hence, there may only be a causal relationship between the proxy record and the longterm trends in temperature and rainfall, which has, more recently, been overlain by cultural impacts.

The causes of century- to millennial-scale climate variability in tropical Africa and the drivers of some of the significant climatic perturbations (e.g. the Medieval Climate Anomaly, MCA, and the Little Ice Age, LIA) are poorly understood (Russell and Johnson, 2005a), though several climatic hypotheses have been suggested. High-resolution records from large lakes (e.g. Russell and Johnson, 2005a; Stager et al., 2007) reveal signals that are smoothed in both space and time, which, whilst useful on a continental scale, are of less relevance when addressing short-term, abrupt or immediate impacts of climate and environmental change on a scale that is relevant to people and policy.

There is a growing body of literature of palaeolimnological records (diatoms, pollen, geochemical and isotopic) from Ugandan crater lakes spanning the last ca. 1000 years at subdecadal resolution (Ssemmanda et al., 2005; Russell et al., 2007; Bessems et al., 2008; Ryves et al., 2011). These studies suggest that some lakes are particularly sensitive to shortterm (decadal- to century-scale) rainfall variability (Russell et al., 2007; Bessems et al., 2008), due to the lake water balance, which is primarily driven by effective moisture (precipitation : evaporation ratio), even in open systems. In general, it can be hypothesised that lake sensitivity to shifts in precipitation (dependent on hydrological connectivity) and catchment disturbance should decline as catchment-to-lake area ratios fall, though the role of groundwater (allowing the exchange of both water and salts to the lake) can become commensurately more important, especially for smaller crater lakes.

However, whilst these studies explore regional coherence of signals through paired lake reconstructions (lakes in a similar catchment geology, but with differing lake morphologies and chemistry), they do not explicitly explore potential drivers of changes in proxy records in a quantitative manner. The objective of this study was to use a paired-lake approach to test the sensitivity of lake sediment records (diatoms, physical properties) in western Uganda to climatic and environmental perturbations (LIA, MCA, 18th-century drought). Specifically, we are testing the hypothesis that the trajectories of lake response (as recorded in the fossil diatom record) would be similar if these external factors are important drivers of lake and catchment change. The present study therefore contributes to the debate about the regional heterogeneity and complexity of known climatic events, and highlights the need for such records to be integrated into continental-scale climate dynamics.

\section{Study sites}

Lakes Nyamogusingiri and Kyasanduka $\left(0^{\circ} 17^{\prime} 4.5^{\prime \prime} \mathrm{S}\right.$, $30^{\circ} 0^{\prime} 46.7^{\prime \prime} \mathrm{E}$ and $0^{\circ} 17^{\prime} 23.2^{\prime \prime} \mathrm{S}, 30^{\circ} 3^{\prime} 0.6^{\prime \prime} \mathrm{E}$ ) are two adjacent crater lakes located within the Bunyaruguru lake cluster (Melack, 1978; Fig. 1). These lakes are situated within the Maramagambo Central Forest Reserve on the ecotone between moist semi-deciduous forest and grass savannah (Langdale-Brown et al., 1964). Reported annual rainfall for lakes Nyamogusingiri and Kyasanduka is in the range of $900-1300 \mathrm{~mm}$ (Lock, 1967). The rainfall in this region is seasonally bimodal, driven by the biannual migration of the intertropical convergence zone (ITCZ), bringing moisture from both the Atlantic and Indian oceans (Nicholson, 1996). Uganda experiences two wet seasons; the first occurs between March and mid-May ("long rains" or "latter rains"; Endfield et al., 2009), and the second season is October to December ("short rains"). Most of the rain falls during the first period. Studies from equatorial East Africa also document links between El Niño-Southern Oscillation (ENSO) events and precipitation, with an excess of precipitation in El Niño years (Nicholson, 1996).

Whilst the two lakes sit within the same catchment geology, despite their close proximity, they differ in both their physical and limnological attributes. Lake Nyamogusingiri is much larger $\left(4.3 \mathrm{~km}^{2}\right)$, with a minimum catchment 


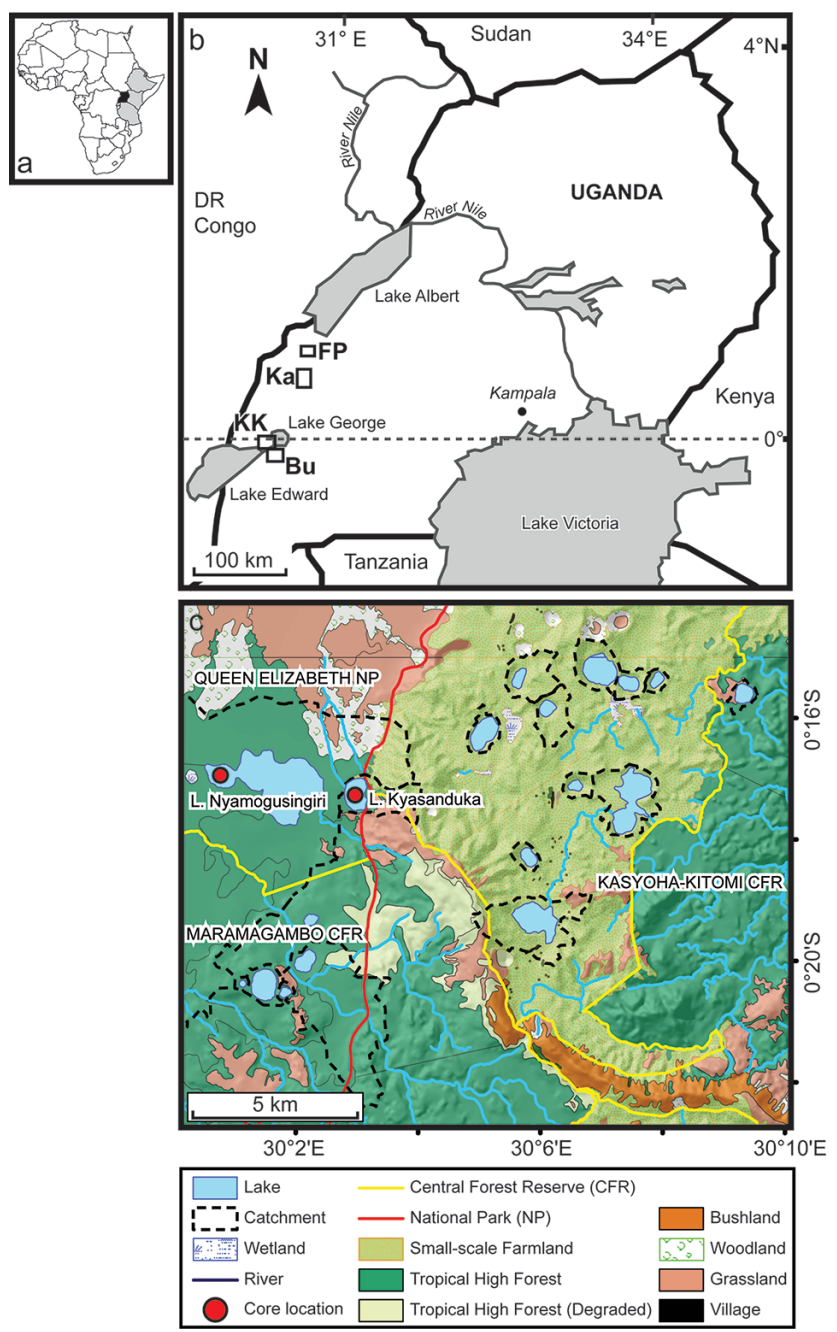

Figure 1. (a) Regional location of Uganda. (b) Map of Uganda showing the four crater lake clusters: Fort Portal (FP), Kasenda (Ka), Katwe-Kikorongo (KK) and Bunyaruguru $(\mathrm{Bu})$, as described by Melack (1978). (c) Bunyaruguru crater lake cluster showing Lake Nyamogusingiri and Lake Kyasanduka.

area: lake ratio $(\mathrm{CA}: \mathrm{L})$ of 11.6 and a higher conductivity $\left(554 \mu \mathrm{S} \mathrm{cm}^{-1}\right)$ than Kyasanduka $\left(0.55 \mathrm{~km}^{2} ; 204 \mu \mathrm{S} \mathrm{cm}^{-1}\right.$; $\mathrm{CA}: \mathrm{L}=4.1)$. Lake Nyamogusingiri is the deeper of the two lakes. Kyasanduka has a maximum recorded depth of $2 \mathrm{~m}$ (Mills, 2009), whilst previous studies have reported that the maximum depth of Lake Nyamogusingiri is $4.6 \mathrm{~m}$ (Melack, 1978). Nyamogusingiri appears to be an amalgamation of several smaller craters, the majority of which form a broad, flat basin (with a depth of $3.9 \mathrm{~m}$ ). To the extreme west of this basin, however, lies a smaller but deeper crater $(12.5 \mathrm{~m})$ which is currently connected to the main basin. A sill exists at a depth of $1.2 \mathrm{~m}$ between these two basins. If the lake level were to lower sufficiently, the two adjoined basins would become two independent, isolated lakes. There is evidence within Nyamogusingiri's deeper basin of previous lower lake levels. Situated around the present shoreline, several metres offshore, are a series of dead trees and emergent tree stumps. These trees are rooted at a depth of ca. $2 \mathrm{~m}$ and may be indicative of a lower lake level in the recent past. The duration of this lowstand would have needed to be of sufficient duration for trees to establish themselves, mature and withstand fluctuating lake levels, before a highstand likely drowned the trees.

\section{Materials and methods}

\subsection{Coring, physical analyses and radiometric dating}

Sediment cores were collected from the deepest part of Lake Nyamogusingiri's deep, west basin $(12.5 \mathrm{~m})$ and Lake Kyasanduka (2 m; Fig. 1) in January 2007 using a HONKajak gravity corer to retrieve the uppermost, unconsolidated sediments, and a Russian peat corer to collect the deeper, consolidated sediments. Multiple cores were taken in parallel drives to ensure overlap between adjacent core sections. The gravity cores were sectioned in the field $(0.5 \mathrm{~cm}$ intervals), and the Russian cores were kept intact and placed in half drain pipes, wrapped in polyethylene film immediately after collection and stored in the dark. After shipping to the UK (2-3 weeks after collection), the samples were kept in dark refrigeration $\left(4^{\circ} \mathrm{C}\right)$ until required for analysis.

The cores from each lake were correlated using a combination of visual stratigraphy, loss-on-ignition (LOI; Dean, 1974) and magnetic susceptibility, and for Kyasanduka by high-resolution diatom analyses in the lower core sections (see Supplement). Composite sequences from both lakes include correlated samples from several individual cores, totalling $127 \mathrm{~cm}$ in Nyamogusingiri and $217 \mathrm{~cm}$ in Kyasanduka (see Supplement for correlation details). Sampling density for physical analyses was completed on contiguous $0.5 \mathrm{~cm}$ intervals and diatom counts at $1 \mathrm{~cm}$ intervals (non-contiguous sampling) on overlapping cores.

The core sequences from both lakes were dated using a combination of ${ }^{210} \mathrm{~Pb}$ and ${ }^{137} \mathrm{Cs}$ for recent sediments and AMS ${ }^{14} \mathrm{C}$ dating for the older core sequences. Lead-210 dates for each core were calculated using the constant rate of supply model (CRS; Appleby, 2001), and compared with stratigraphic dates determined from the ${ }^{137} \mathrm{Cs}$ record. AMS ${ }^{14} \mathrm{C}$ dating was carried out on terrestrial macrofossils or charcoal (both $>250 \mu \mathrm{m}$ ). A total of 16 dates were obtained from the 2 core sequences (Table 1). A $1 \mathrm{~cm}$ thick sediment sample was taken from the selected horizon and wet sieved through $250 \mu \mathrm{m}, 125 \mu \mathrm{m}$ and $63 \mu \mathrm{m}$ meshes with deionised water. The various residues were transferred into labelled petri dishes, and samples were picked using stainless steel forceps under a Leica dissecting microscope at $\times 10$ $\times 50$ magnification. The picked samples were transferred into sterile glass bottles and dried at $40^{\circ} \mathrm{C}$. All of the samples for radiocarbon dating were subject to an acid-alkali-acid 
Table 1. Calibrated radiocarbon ages for all samples from Lake Nyamogusingiri and Lake Kyasanduka (* denotes date rejected from age model).

\begin{tabular}{|c|c|c|c|c|c|c|}
\hline Lab. code & $\begin{array}{l}\text { Depth } \\
(\mathrm{cm})\end{array}$ & $\begin{array}{l}\text { Dated } \\
\text { material }\end{array}$ & $\begin{array}{l}\text { Conventional }{ }^{14} \mathrm{C} \\
\text { age } \pm 1 \sigma \text { error }\end{array}$ & $\begin{array}{l}\text { Median probability } \\
(\mathrm{AD} / \mathrm{BC})\end{array}$ & $\begin{array}{l}2 \sigma \text { calibrated } \\
{ }^{14} \mathrm{C} \text { age range }(\mathrm{AD} / \mathrm{BC})\end{array}$ & $\begin{array}{l}\text { Relative } \\
\text { area }(\%)\end{array}$ \\
\hline \multicolumn{7}{|c|}{ Lake Nyamogusingiri } \\
\hline \multirow[t]{2}{*}{ SUERC-18911 } & 61.5 & Leaf/charcoal & $419 \pm 37$ & 1467 & $1422-1522$ & 85.03 \\
\hline & & & & & $1574-1585$ & 1.53 \\
\hline \multirow{3}{*}{ SUERC-19066 } & & & & & $1587-1625$ & 13.44 \\
\hline & 92.5 & Leaf/charcoal & $685 \pm 35$ & 1299 & $1265-1319$ & 64.48 \\
\hline & & & & & $1351-1390$ & 35.52 \\
\hline SUERC-19067 & 108.5 & Wood/charcoal & $795 \pm 35$ & 1239 & $1180-1278$ & 100 \\
\hline \multirow[t]{2}{*}{ *SUERC-18396 ${ }^{1}$} & 121.5 & Wood & $494 \pm 37$ & 1426 & $1326-1343$ & 4.17 \\
\hline & & & & & $1394-1454$ & 95.82 \\
\hline \multirow[t]{2}{*}{ *POZ-26361 ${ }^{1}$} & 126.5 & Charcoal & $415 \pm 30$ & 1464 & $1429-1518$ & 90.25 \\
\hline & & & & & $1594-1618$ & 9.74 \\
\hline \multicolumn{7}{|l|}{ Lake Kyasanduka } \\
\hline \multirow[t]{4}{*}{ SUERC-16174 } & 90.5 & Leaf & $227 \pm 35$ & 1750 & $1528-1551$ & 2.76 \\
\hline & & & & & $1634-1685$ & 41.6 \\
\hline & & & & & $1732-1808$ & 44.06 \\
\hline & & & & & $1928-1952$ & 11.72 \\
\hline \multirow[t]{3}{*}{ *SUERC-19070² } & 134.5 & Charcoal & $995 \pm 35$ & 1036 & $983-1058$ & 61.75 \\
\hline & & & & & $1069-1071$ & 0.29 \\
\hline & & & & & $1076-1154$ & 37.96 \\
\hline \multirow[t]{2}{*}{ SUERC-18397 } & 167.5 & Leaf & $362 \pm 37$ & 1538 & $1449-1530$ & 49.24 \\
\hline & & & & & $1538-1635$ & 50.76 \\
\hline \multirow[t]{2}{*}{ SUERC-16175 } & 169 & Charcoal & $568 \pm 37$ & 1353 & $1300-1368$ & 58.94 \\
\hline & & & & & $1381-1429$ & 41.06 \\
\hline \multirow[t]{2}{*}{ SUERC-16176 } & 184 & Wood & $516 \pm 37$ & 1416 & $1319-1351$ & 15.74 \\
\hline & & & & & $1390-1447$ & 84.26 \\
\hline \multirow[t]{2}{*}{ SUERC-18988 } & 189.5 & Wood & $480 \pm 37$ & 1431 & $1332-1337$ & 0.70 \\
\hline & & & & & $1397-1470$ & 99.30 \\
\hline \multirow[t]{2}{*}{ SUERC-19065 } & 189.5 & Charcoal & $565 \pm 35$ & 1354 & $1302-1366$ & 56.87 \\
\hline & & & & & $1383-1429$ & 43.13 \\
\hline SUERC-19071 & 192.5 & Wood & $905 \pm 35$ & 1119 & $1037-1209$ & 100 \\
\hline *SUERC-183983 & 192.5 & Charred wood & $2700 \pm 37$ & -853 & -914 to -802 & 100 \\
\hline SUERC-16173 & 202.5 & Wood & $792 \pm 35$ & 1240 & $1182-1279$ & 100 \\
\hline \multirow[t]{2}{*}{$* \mathrm{POZ}-26360^{2}$} & 206.5 & Charcoal & $1830 \pm 30$ & 182 & $86-107$ & 3.62 \\
\hline & & & & & $120-252$ & 96.38 \\
\hline
\end{tabular}

${ }^{1}$ Potentially modern contamination; ${ }^{2}$ charcoal - reworking; ${ }^{3}$ uncertainty surrounding composition of dating material.

(AAA) pre-treatment before analysis, combusted to $\mathrm{CO}_{2}$ and reduced to an iron-graphite mixture (Slota et al., 1987) at the NERC Radiocarbon Facility before ${ }^{14} \mathrm{C}$ analysis at the SUERC AMS laboratory. All dates were calibrated and age models developed using the CLAM for R program (Blaauw, 2010) and the IntCal09 calibration curve (Reimer et al., 2009). A number of age models were run based upon 0.3 to 0.7 span smooth spline interpolation. A smoothing parameter of 0.5 was selected for both records, as it enabled sufficient flexibility in the sediment age-depth relationship to fit the radiocarbon data without producing a final model with an age reversal, which was deemed unlikely.

\subsection{Diatom analysis}

For diatom analysis, cores were sampled at $1 \mathrm{~cm}$ intervals (non-contiguous), which corresponds to a sample temporal resolution of 1-20 years for Lake Nyamogusingiri and less than 1-10 years for Lake Kyasanduka (depending on the sedimentation rate).

Samples for diatom analysis were prepared following the waterbath method of Renberg (1990). A total of 133 and 278 samples from Nyamogusingiri and Kyasanduka respectively were counted (including overlapping samples). Strewn slides were mounted in Naphrax, and at least 300 valves per sample were counted in parallel transects under oil-immersion 
phase-contrast light microscopy $(\mathrm{LM})$ at $\times 1000$ magnification on a Leica DMRE research microscope. A variety of general (e.g. Krammer and Lange-Bertalot, 1986-1991; Patrick and Reimer, 1966, 1975) and regional floras (e.g. Gasse, 1986; Cocquyt, 1998) were consulted, and valves identified to species level where possible. The dissolution of the diatom valves was assessed using a two-scale system (pristine and dissolved (F index); Ryves et al., 2001). This ratio varies from 0 (all valves partly dissolved) to 1 (perfect preservation). Diatom concentrations were estimated by adding a known number of inert microspheres to the samples (Battarbee and Kneen, 1982).

\subsection{Numerical methods}

The stratigraphical diatom data from each core were divided into assemblage zones using optimal sum of squares partitioning (Birks and Gordon, 1985) by the ZONE program (version 1.2; Juggins, 2002). Diatom-inferred conductivity was calculated using the Ugandan crater lake model of Mills and Ryves (2012).

\subsubsection{Indirect ordinations}

Ordination analyses were carried out using CANOCO 4.5 (ter Braak and Šmilauer, 2002) to identify the predominant trends within the diatom abundance data. Initially, a detrended correspondence analysis (DCA; Hill and Gauch, 1980), with detrending by segments and down-weighting of rare species, was used to explore the main patterns of taxonomic variation within each site and to estimate the compositional gradient lengths of the first few DCA axes. The diatom percentage data were transformed using log transformation in an attempt to reduce clustering of abundant or common taxa at the centre of origin (Leps and Šmilauer, 2003). The gradient lengths allow the determination of the most appropriate response model for further analysis, with thresholds of 1.5 SD units determining the choice of linear $(<1.5 \mathrm{SD})$ or unimodal models (>1.5 SD; ter Braak and Prentice, 1988).

\subsubsection{Direct ordinations}

To investigate the factors that might be driving changes in the aquatic environment, a set of predictor (e.g. organic and minerogenic accumulation rates, atmospheric $\Delta^{14} \mathrm{C}$ residual series, regional lake levels; Table S1, Supplement) and response (diatom taxa) variables was created. Redundancy analysis was undertaken using a combination of RDA (linear) and CCA (unimodal) response models in Canoco 4.5 (following the method of Bradshaw et al., 2005). Preliminary analyses showed that the diatom response data was significantly correlated with sediment age (DCA axis $1 ; p<$ 0.001). As a result, sediment age was included as a covariable in subsequent ordinations to partial out the variance resulting from this autocorrelation (Odgaard, 1994).
To explore and attempt to explain changes in drivers through time, the assigned diatom zones (Ks-1 to Ks-6 and Ny-1 to Ny-6) were analysed using RDA. As dates for the drivers (predictors) and diatom samples had to match for this analysis, and data were not available for all predictors at this resolution, some diatom samples were excluded from both Kyasanduka (21) and Nyamogusingiri (1). The Ugandan diatom data sets alongside the local drivers (Table S1 in the Supplement) provided the most recent data sets (up to AD 2007), and for analysis using "predictor" variables from other studies, modification of the data sets was undertaken. In this instance, the most recent zone in both cores (zone 6) was split into three (Ks-6a,b,c and Ny-6a,b,c), and in both cases, zone 6c (post-AD 2000) was excluded from all RDAs, as no other "predictor" data corresponded to this time slot. Zones $6 \mathrm{a}$ and $6 \mathrm{~b}$ in both systems represent pre-AD 1975 and post-AD 1975, respectively. This allowed a number of important predictor data sets to be included that were only as recent as the mid-1970s (Lake Naivasha, Lake Victoria and Lake Edward). Zone 6b was thus analysed using a reduced set of predictor variables, while zone $6 \mathrm{a}$ was analysed using the full set of predictor variables (see Table S1, Supplement). For each sample group, a DCA was applied to the diatom data to ascertain the gradient length, and then partial RDA was undertaken (as gradient length was $<1.5 \mathrm{SD}$ ). Analyses used log transformation of percentage species data and Bonferroni-adjusted forward selection to identify a subset of significant explanatory variables. Monte Carlo permutation tests ( $n=999$ unrestricted permutations) under a reduced model were used to test the significance of the selected variables.

\section{Results}

\subsection{Core correlation and chronological analysis}

For both lakes, a master core sequence was created from the overlapping core sequences. Initially, this correlation was derived using the coring depths as recorded in the field; further physical and stratigraphical analyses were employed to strengthen the correlation of both lake sequences. This correlation process was straightforward and involved the use of LOI for Lake Nyamogusingiri (Supplement, Fig. S1). However, the correlation of the overlapping core sections from Lake Kyasanduka was slightly more complex, and a final sequence was derived through the use of LOI profiles and detailed diatom analyses of the lower core sections (Supplement, Figs. S2 and S3).

Age models were constructed for both lakes using highresolution ${ }^{210} \mathrm{~Pb}$ and ${ }^{137} \mathrm{Cs}$ analyses of the upper sediments and AMS radiocarbon dating of terrestrial macrofossils for the lower core sequences (Table 1). The resulting age models are presented in Figs. 2 and 3. A small number of dates were rejected from the models (Table 1), details and explanations 

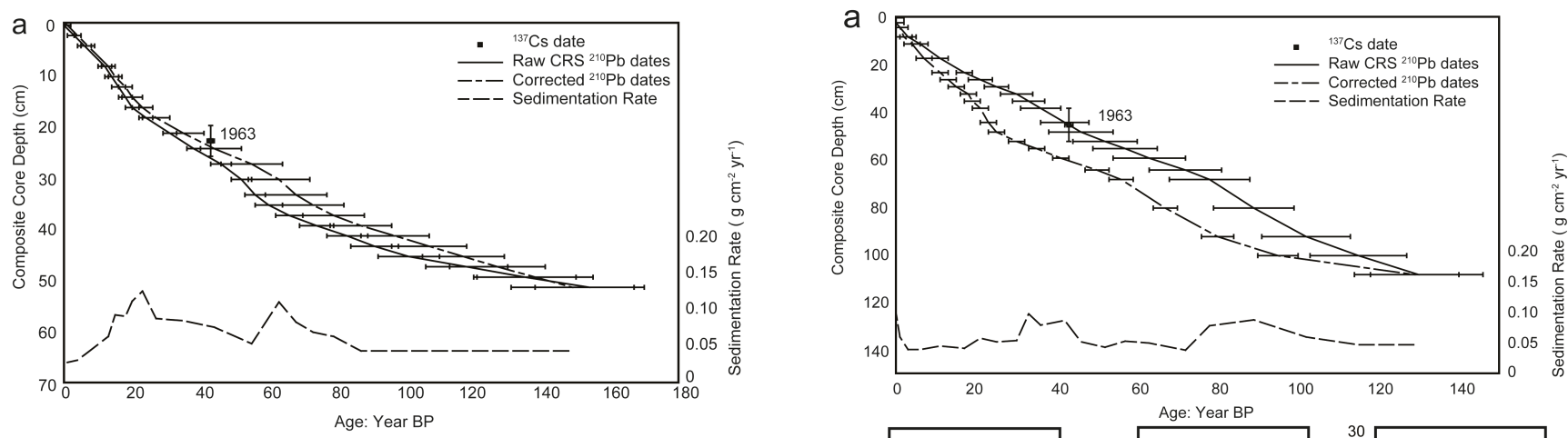
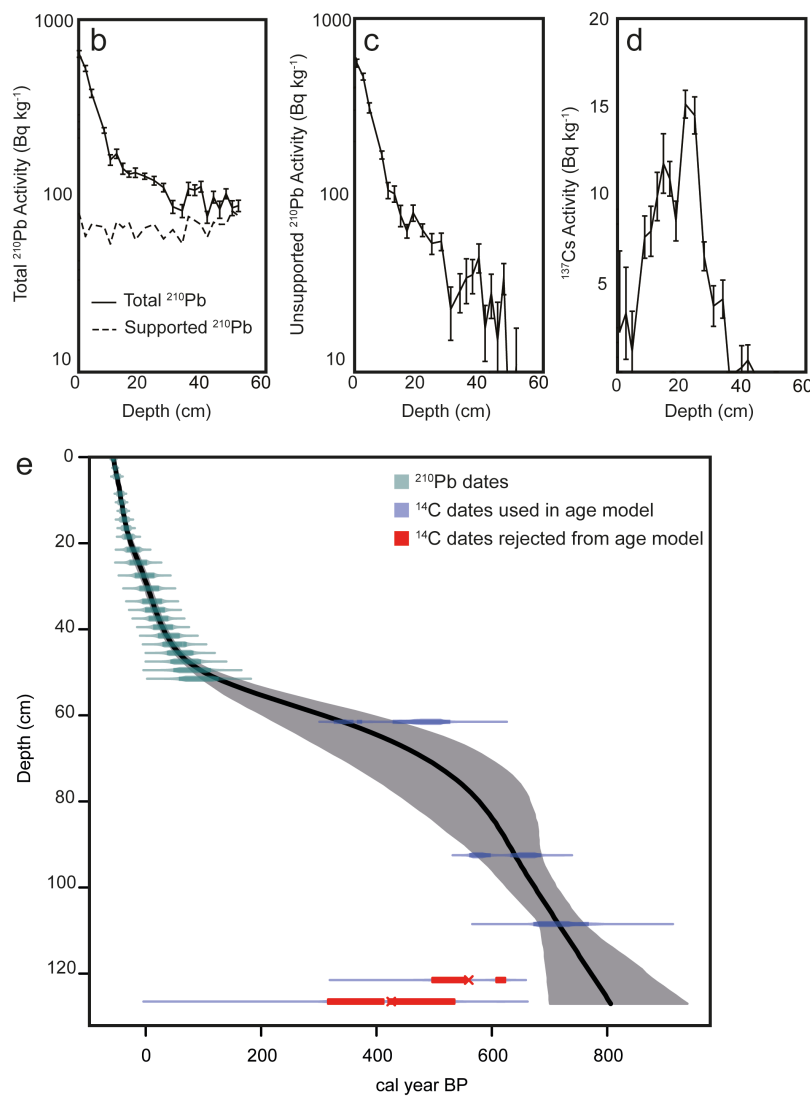

Figure 2. Radiometric dating of the Lake Nyamogusingiri sediment core (a) ${ }^{210} \mathrm{~Pb}$ and ${ }^{137} \mathrm{Cs}$ chronology and sedimentation rate. Fallout radionuclides (versus depth) of (b) supported and unsupported ${ }^{210} \mathrm{~Pb}$, (c) unsupported ${ }^{210} \mathrm{~Pb}$, (d) ${ }^{137} \mathrm{Cs}$ concentrations (note that the ${ }^{210} \mathrm{~Pb}$ concentration data is a logarithmic scale), and (e) final age model; the grey envelope highlights the chronological uncertainty in the record.

for which are proposed in the Supplement. A smooth spline function of 0.5 was selected, as it provided the maximum degree of age model flexibility. Smooth functions less than 0.5 resulted in age reversals for both sites, whilst values greater than 0.5 resulted in increasingly rigid age models with smaller, less realistic age uncertainty.
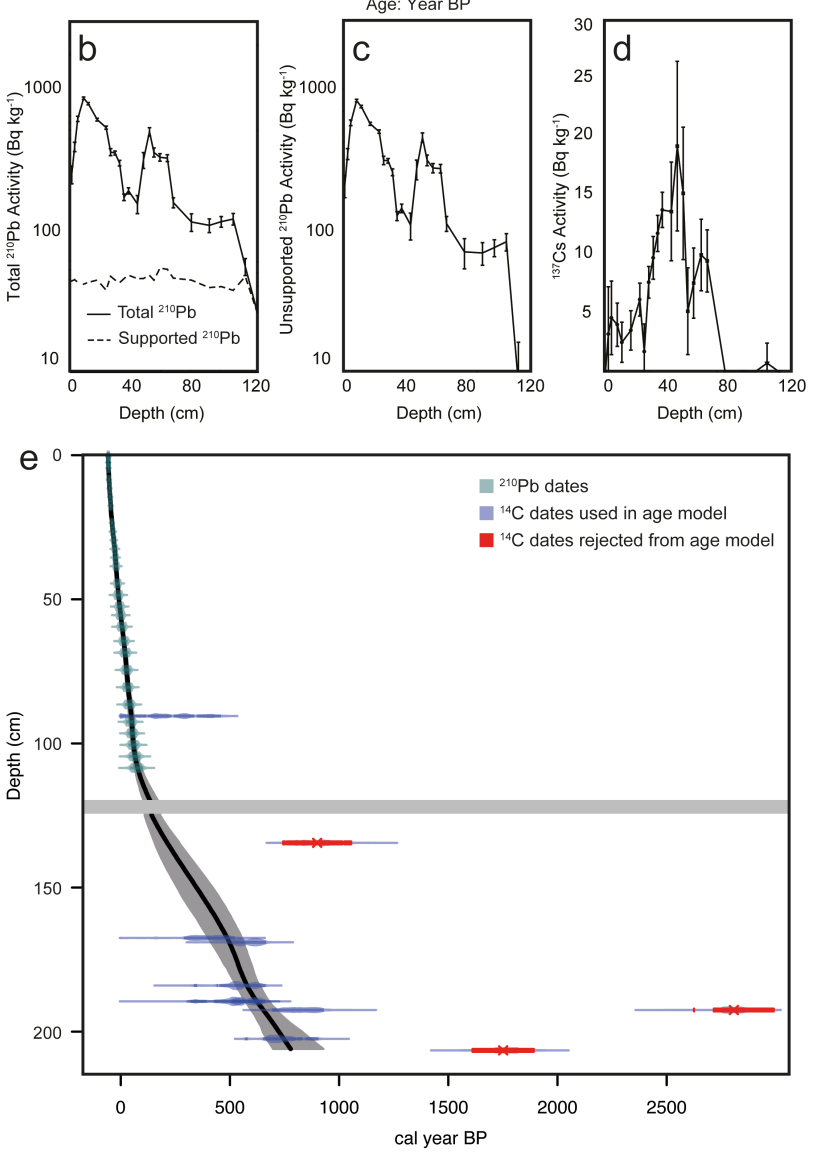

Figure 3. Radiometric dating of the Lake Kyasanduka sediment core (a) ${ }^{210} \mathrm{~Pb}$ and ${ }^{137} \mathrm{Cs}$ chronology and sedimentation rate. Fallout radionuclides (versus depth) of (b) supported and unsupported ${ }^{210} \mathrm{~Pb}$, (c) unsupported ${ }^{210} \mathrm{~Pb}$, (d) ${ }^{137} \mathrm{Cs}$ concentrations, and (e) final age model; the grey envelope highlights the chronological uncertainty in the record. The grey band at ca. $125 \mathrm{~cm}$ is likely coincident with a period of inferred catchment in wash (simultaneous deposition event), as evidenced by high magnetic susceptibility, low organic content (Figs. S2 and S3, Supplement) and an increase in the number of aerophilous taxa in the core. 
a. Lake Nyamogusingiri diatom stratigraphy

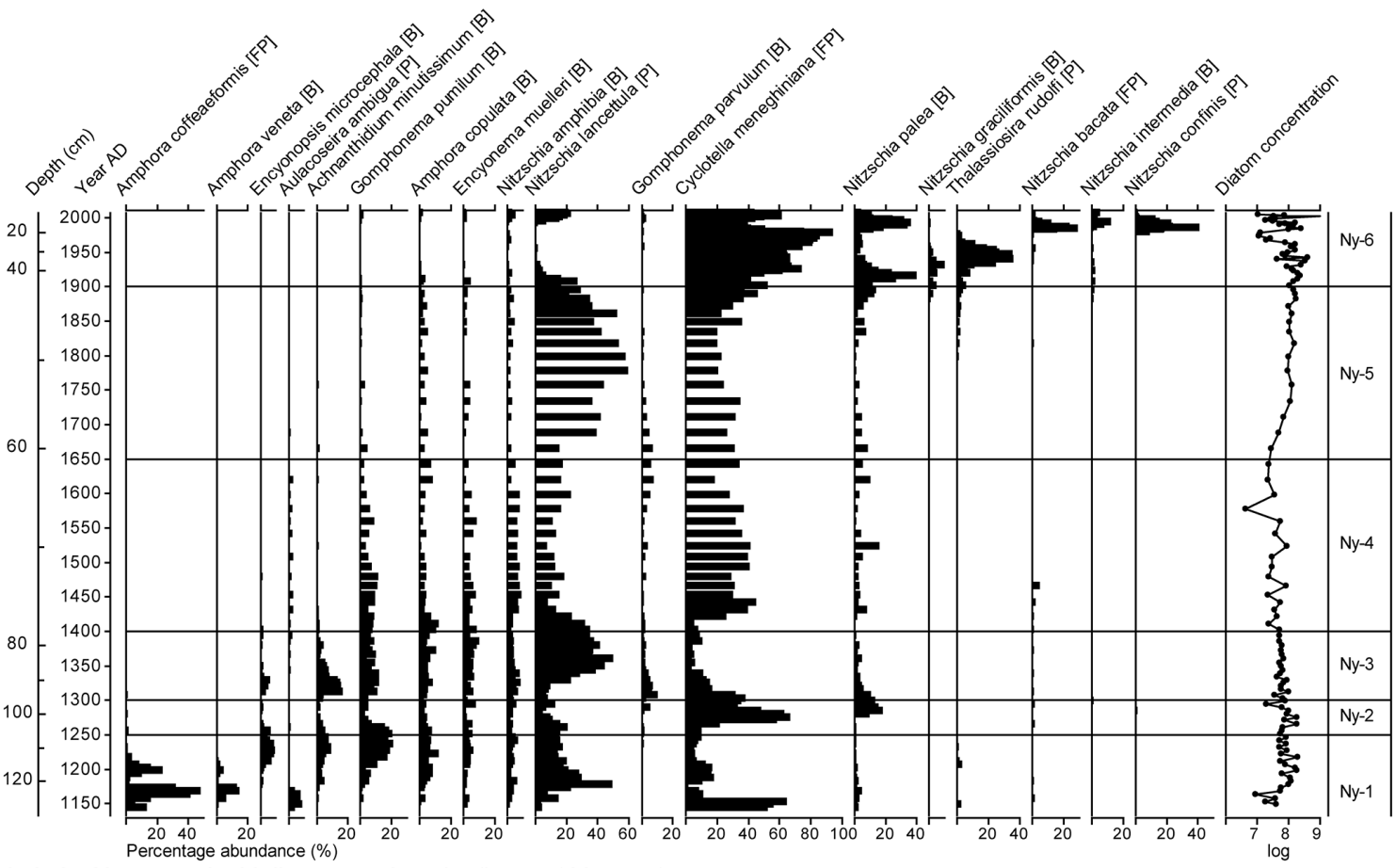

b. Lake Nyamogusingiri diatom stratigraphy (last $c .100$ years)

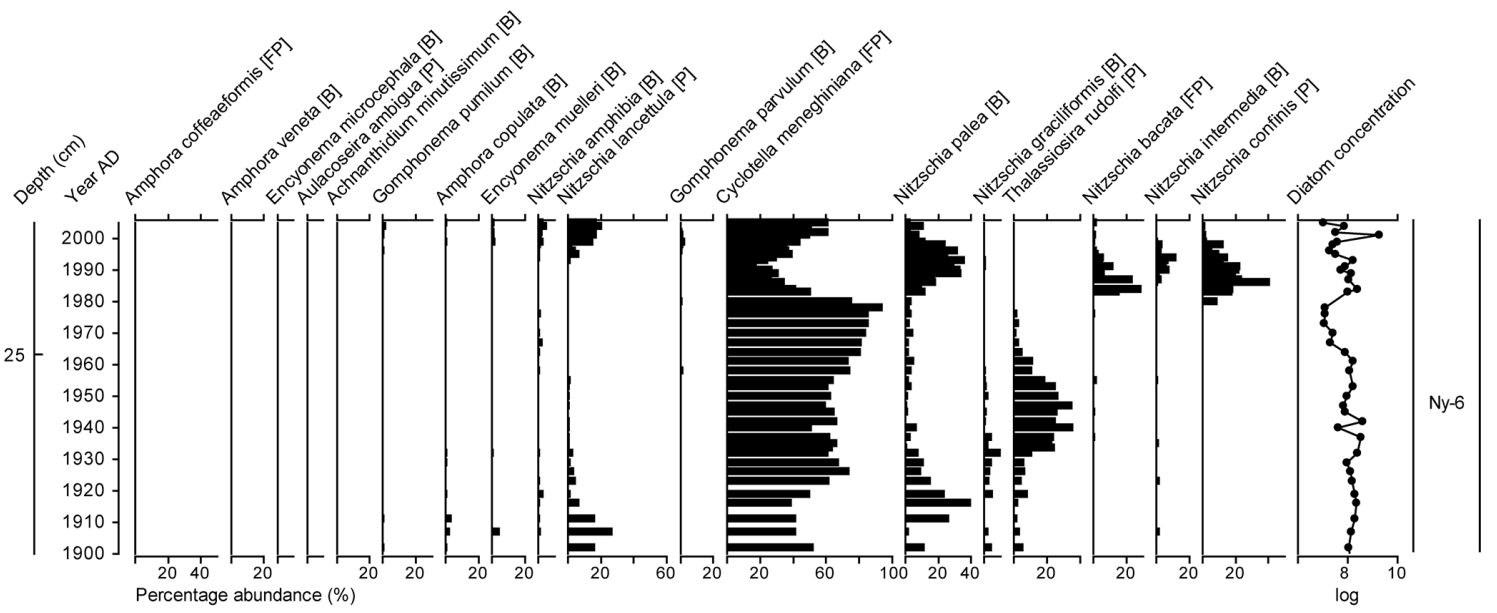

Figure 4. Diatom stratigraphy from (a) Lake Nyamogusingiri (full record), (b) detail of the last 100 years from Lake Nyamogusingiri and (c) Lake Kyasanduka showing selected taxa (> 8\% in any one sample), ordered by weighted-averaging optimum (ascending) and log diatom concentration (valves per gram of dry sediment). Diatom zones were obtained using the optimal sum of squares method (Birks and Gordon, 1985) in the ZONE program (Juggins, 2002). The letters given in closed brackets after the species name denote the assigned habitat for this study: A is Aerophilous, B is Benthic/periphytic, FP is Facultatively planktonic and P is Planktonic.

\subsection{Diatom record}

\subsubsection{Lake Nyamogusingiri (Fig. 4a and b)}

- Ny-1, ca. AD 1150-1250 (127-102 cm). In the lower part of this core, the diatom assemblage is dominated by Cyclotella meneghiniana and low abundances of the salt-tolerant taxon Amphora coffeaeformis, indicating a shallow, slightly saline environment (Gasse, 1986;
Gasse et al., 1997). The appearance of Aulacoseira ambigua, an increase in the abundance of Nitzschia lancettula, and a reduction in A. coffeaeformis and $C$. meneghiniana attest to a short-lived fresher phase. The increase in A. coffeaeformis, in conjunction with the salt-tolerant $A$. veneta, suggests periods of higher salinity. These two saline events are punctuated by a freshwater event (ca. AD 1180) characterised by a deepening 


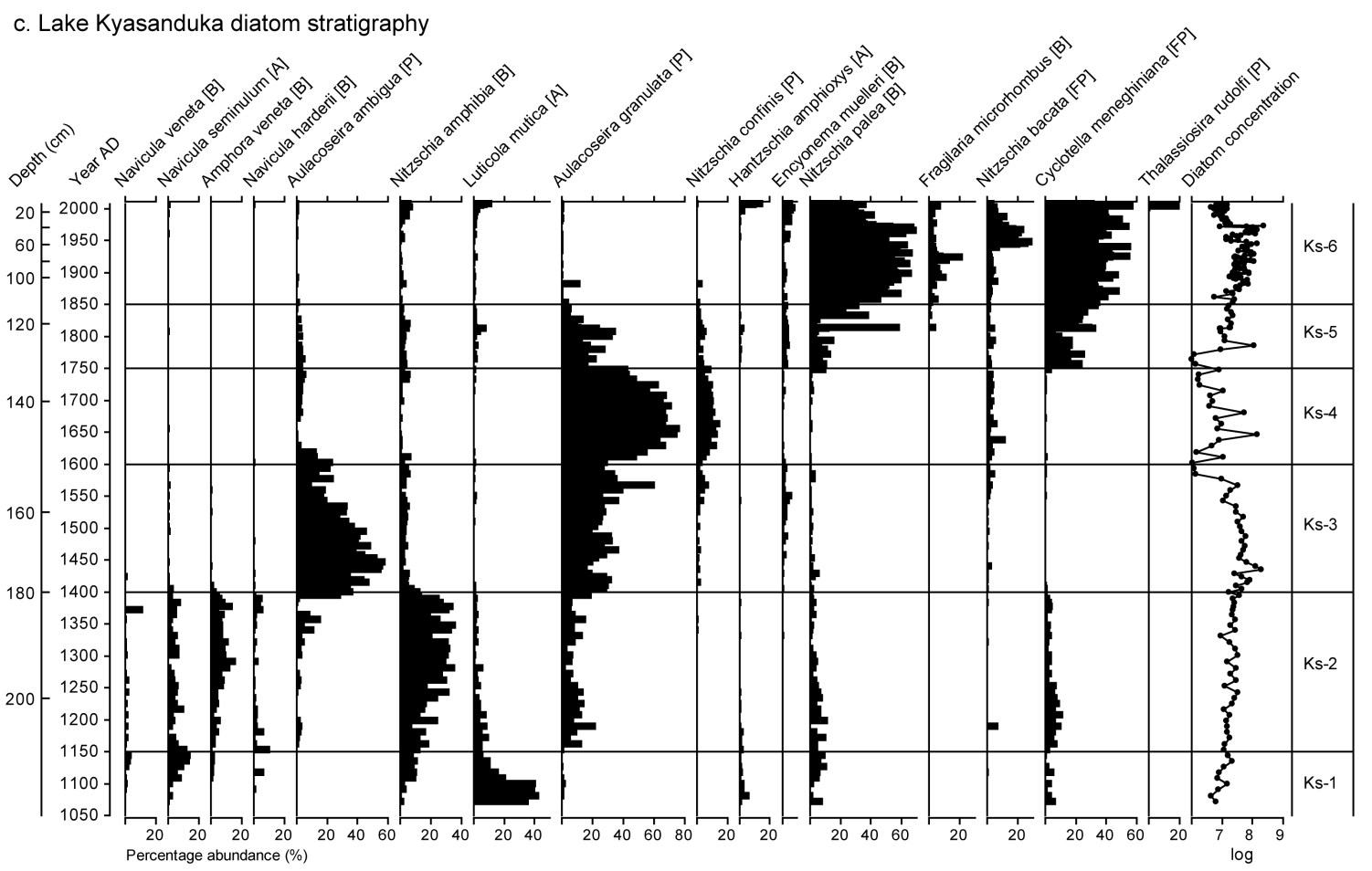

Figure 4. Continued.

of the lake, indicated by a rise in $N$. lancettula (Stager et al., 2005). A deepening and freshening of the lake is inferred by the higher abundance of $N$. lancettula and low C. meneghiniana, although the dominance of benthic and periphytic species (e.g. Encyonema microcephala, Gomphonema pumilum, Amphora copulata) suggests that marginal lake areas are important contributors to the sediment record.

- Ny-2, ca. AD 1250-1300 (102-94 cm). This zone is dominated by $C$. meneghiniana, with a decrease in $A$. ambigua and $N$. lancettula, perhaps suggesting a lowering of lake levels or a breakdown of water column stratification. Increased turbidity and nutrient-rich phases are typified by high abundances and fluxes of $C$. meneghiniana and Nitzschia palea (Leland and Porter, 2000; Tuchman et al., 2006), and may attest to a decline in water clarity in this aquatic ecosystem (Lange-Bertalot, 1979; van Dam et al., 1994; Charles et al., 2006), especially given that many of the benthic and periphytic taxa (e.g. E. microcephala, G. pumilum and Encyonema muelleri) are generally at very low abundances $(<5 \%)$.

- Ny-3, ca. AD 1300-1400 (94-76 cm). Higher lake levels with a stratified water column are indicated by high abundances of $N$. lancettula (Stager et al., 2005). The increase in the abundance of benthic and periphytic taxa also suggests a decrease in turbidity during this phase.
- Ny-4, ca. AD 1400-1650 $(76-60 \mathrm{~cm})$. A return to lower lake levels (reduction in N. lancettula and A. ambigua) is observed during this phase at Lake Nyamogusingiri. Benthic and periphytic taxa (G. pumilum, A. copulata and N. amphibia) are also important (abundances greater than $7 \%$ ), suggesting persistent aquatic vegetation (Stager and Johnson, 2007) and the suggestion of low turbidity. The dominance of $C$. meneghiniana during this phase could be a result of increased conductivity as lake levels lower. However, this is not supported by the diatom-inferred conductivity, and may be a result of a change in ionic composition, without a change in concentration, as a result of salts being exchanged with groundwater.

- Ny-5, ca. AD 1650-1900 (60-44 cm). High lake levels and stratification of the water column are once again inferred, as $N$. lancettula dominates the zone. Many of the benthic and periphytic taxa have either all but disappeared (G. pumilum) or are present in very low abundances $(<5 \%)$, and may suggest that lake levels are at their highest in Nyamogusingiri at this time.

- Ny-6, ca. AD 1900-2007 (44-18 cm). During the last ca. 100 years (Fig. 4b), a major change is observed in the record. The increase in abundance of $N$. palea and $C$. meneghiniana is coincident with an increase in the influx of sediment and organic matter, perhaps as a result of catchment disturbance (Sabater, 2000; Mills, 2009). 
Studies have shown that $N$. palea thrives in habitats that are organically enriched, and is capable of living and sustaining large populations in very turbid conditions (Tuchman et al., 2006).

Enhanced catchment destabilisation (vegetation removal) in response to climatic stressors (e.g. hydrological connectivity) and cultural impacts (clearance for agriculture) likely led to the delivery of a large quantity of nutrients to the lake, increasing primary (diatom) productivity. The reduction of littoral/periphytic taxa (e.g. E. muelleri, G. parvulum and G. pumilum) suggests that conditions were unsuitable for the growth of aquatic vegetation, as a consequence of high turbidity and rising salinity (indicated by the appearance of Thalassiosira rudolfi; Stager, 1984; Gasse, 1986); N. lancettula disappears almost completely from the record. Increasing nutrient inputs to the lake are likely a consequence of human-induced catchment disturbance. For example, the construction and operation of a safari lodge (Jacana Lodge, completed in 1998) on the shores of the larger basin would likely have delivered large amounts of catchment sediment and nutrients to the lake system.

\subsubsection{Lake Kyasanduka (Fig. 4c)}

- Ks-1, ca. AD 1050-1150(217-208 cm). The presence of the aerophilous species in the earliest period suggests a very shallow lake or swampy/water-logged conditions (Gasse, 1986).

- Ks-2, ca. AD 1150-1400 (208-179 cm). During this period, the lake is dominated by aquatic vegetation, as suggested by the high abundances of Nitzschia amphibia and other periphytic species. The presence of Amphora veneta and $C$. meneghiniana may attest to slightly more saline conditions at this time. There are three small perturbations in this relatively uniform phase, where there are short-lived peaks in the abundance of A. ambigua, perhaps suggesting a rapid freshening of the lake system (Chalié and Gasse, 2002; Stager et al., 2005).

- Ks-3, ca. AD 1400-1600 (179-150 cm). The appearance of $A$. ambigua and the decline in periphytic species indicates an opening of the lake waters and a reduction in the available habitat for littoral vegetation. Aulacoseira ambigua dominates the majority of this zone, although A. granulata increases in importance throughout, becoming the dominant taxon towards AD 1600. Aulacoseira ambigua has a high light requirement and is indicative of well-mixed, less turbid conditions. The availability of silica (in particular, a high $\mathrm{Si}: \mathrm{P}$ ratio) may also likely be responsible for the dominance of Aulacoseira species in this zone and Ks-4 (Kilham et al., 1986; Owen and Crossley, 1992; Fritz et al., 1993; Barker et al., 2002).
- Ks-4, ca. AD 1600-1750 (150-133 cm). The sharp decline in and then disappearance of $A$. ambigua and its replacement by $A$. granulata v. angustissima suggests a shallow, well-mixed, turbid lake (Stager et al., 1997). The increase in turbidity is likely responsible for a decline in A. ambigua due to the reduction of light intensity by sediment resuspension under frequent mixing of the entire, shallow, water column, which would also maintain high $\mathrm{Si}$ : $\mathrm{P}$ by enhancing $\mathrm{Si}$ release from sediments. In support of these interpretations, diatom concentration is the lowest of any zone, suggesting lower productivity in a turbid lake (as expected under a high $\mathrm{Si}: \mathrm{P}$ ratio).

- Ks-5, ca. AD 1750-1850 (133-113 cm). This period marks a major change in the diatom flora. The abundance of A. granulata v. angustissima declines and there is an increase in $C$. meneghiniana and $N$. palea. The presence of $A$. granulata v. angustissima in the early part of this zone, in conjunction with aerophilous and shallow water species, suggests a turbid, shallow environment, although replacement of Aulacoseira by Nitzschia (and to some extent the nutrient-indicating $C$. meneghiniana) suggests a later reduction in the $\mathrm{Si}: \mathrm{P}$ ratio.

- Ks-6, ca. AD 1850-2007 (113-0 cm). The lake experienced rapid infilling from this point, with over a metre of sediment deposited in the last ca. 150 years. The decline of A. granulata and its replacement by $N$. palea and $C$. meneghiniana is indicative of a further decline in the $\mathrm{Si}$ : $\mathrm{P}$ ratio. Nitzschia palea is a species highly tolerant to organic pollution (Sabater, 2000), as well as being suggestive of eutrophic/hyper-eutrophic conditions (van Dam et al., 1994); both N. palea and C. meneghiniana have been associated with waters with a heavy load of decomposed organic matter (Sabater, 2000). This may be the result of an increase in nutrients and organic matter from the catchment following deforestation and/or the onset of agriculture. Nitzschia palea is a species common in water bodies draining agricultural land (Leland and Porter, 2000). The appearance of Fragilaria microrhombus in ca. AD 1850 is also worthy of note, and perhaps marks the introduction of fish to the lake and the increasing impacts that humans are exerting on these ecosystems (Cholnoky, 1970).

\section{Discussion}

\subsection{Lake-level and conductivity reconstructions}

Relative lake levels for each of the core sequences were reconstructed using the percentage planktonic taxa (Fig. 5a and $\mathrm{b})$. The reconstructed lake-level records from lakes 
a. Lake Nyamogusingiri summary data

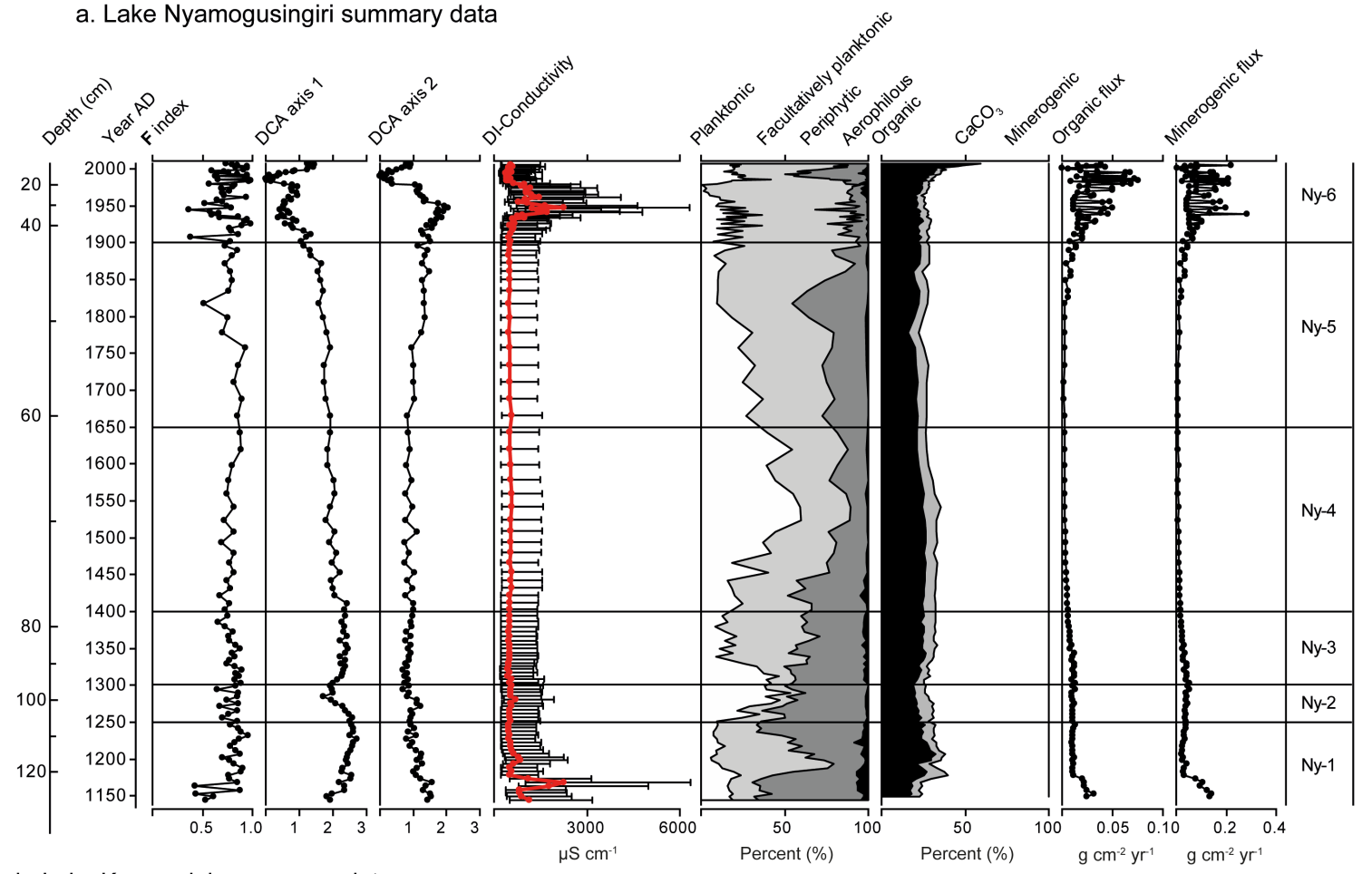

b. Lake Kyasanduka summary data

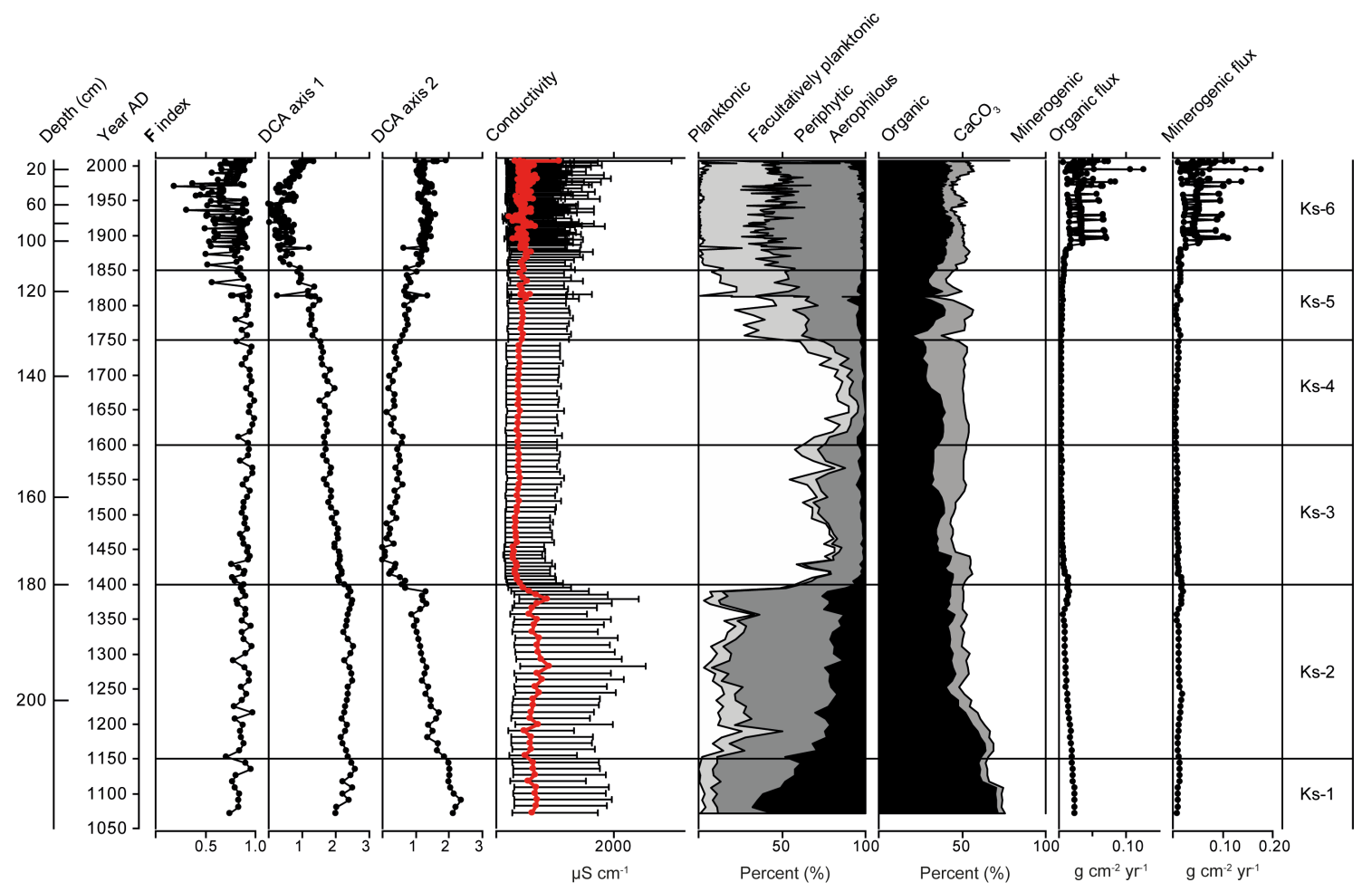

Figure 5. Summary information from the (a) Lake Nyamogusingiri and (b) Lake Kyasaduka sediment cores, including the $\mathbf{F}$ index (diatom valve preservation; Ryves et al., 2001), DCA axes 1 and 2 sample scores, and the diatom-inferred (DI) conductivity (red line) and associated jack-knife error (RMSEP $=0.256 \mathrm{log}$ units) alongside a diatom habitat summary and the results of LOI and calculated organic and minerogenic flux rates. 


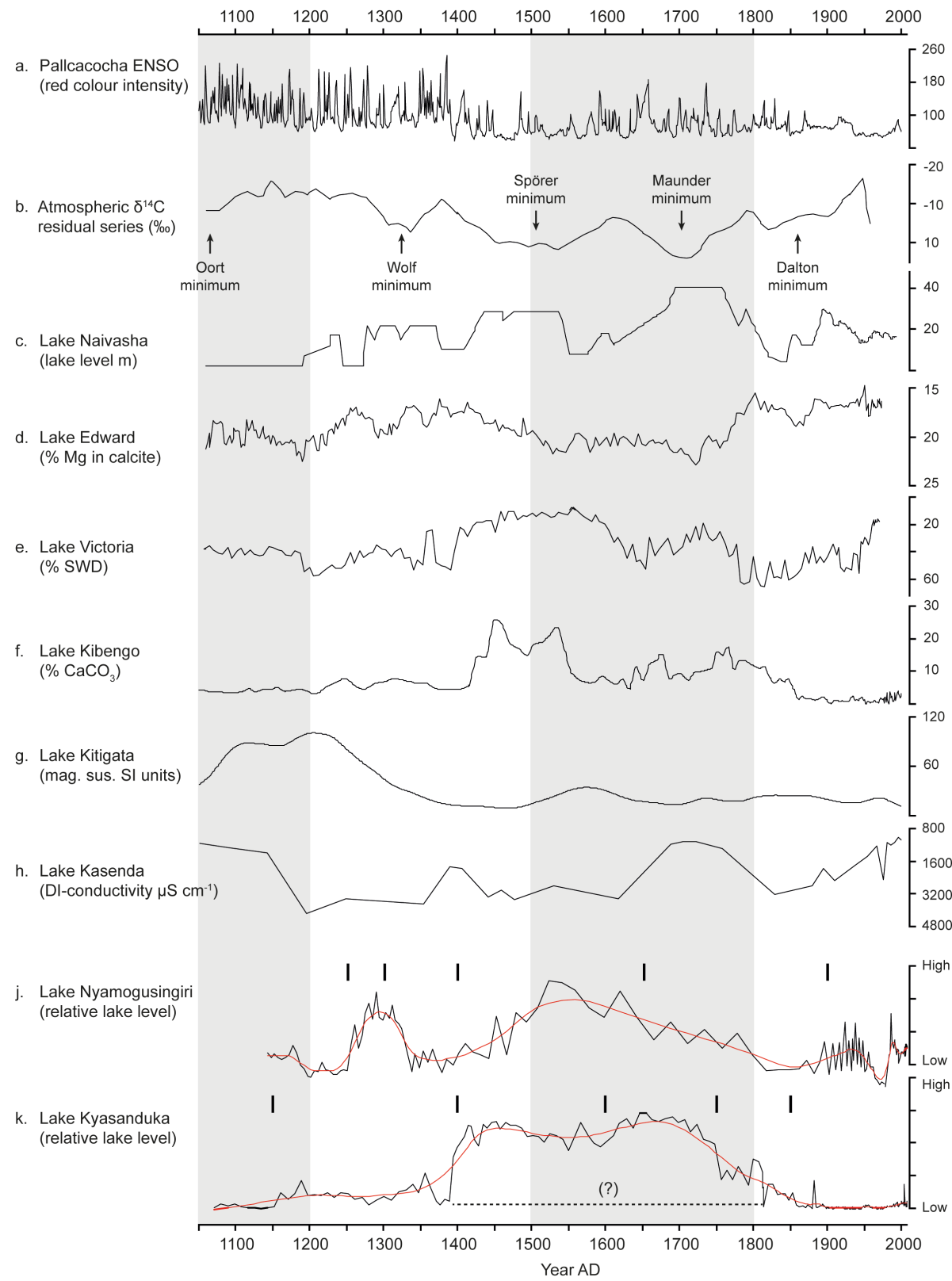

Figure 6. Comparison of climate drivers: (a) Laguna Pallcacocha ENSO frequency (Moy et al., 2002), (b) atmospheric $\Delta^{14} \mathrm{C}$ residual series (sunspot minima; Stuiver and Brauzanias, 1989 - inverted $y$ axis) and regional lake levels in East Africa: (c) Lake Naivasha lake level (Verschuren et al., 2000), (d) Lake Edward \% Mg (Russell and Johnson, 2007 - inverted y axis), (e) Lake Victoria shallow water diatoms (Stager et al., 2005 - inverted $y$ axis), (f) Lake Kibengo \% $\mathrm{CaCO}_{3}$ (Russell et al., 2007), (g) Lake Kitigata magnetic susceptibility (Russell et al., 2007) and (h) Lake Kasenda DI conductivity (Ryves et al., 2011 - inverted y axis). Inferred lake levels from (j) Lake Nyamogusingiri and (k) Lake Kyasanduka are also shown alongside statistical zones (short parallel lines above the curves); the smoothed lake-level curve for both lakes (red) was constructed using a lowess smooth $(0.1 \mathrm{span})$ in C2. The alternative lake level for Kyasanduka is shown by the dashed line, which indicates a lower lake level if the control on the diatom species abundance is controlled by the $\mathrm{Si}: \mathrm{P}$ ratio. The shaded areas represent the MCA (AD 1000-1200) and the main phase of the LIA (AD 1500-1800).

Nyamogusingiri and Kyasanduka (Fig. 6j and k) are independent of reconstructed conductivity in these systems (Fig. 5a and $b$ ). The changes in diatom habitat preference in both cores may suggest lake-level fluctuations in both systems, yet in many cases these are not matched with a change in (diatom-inferred) lake conductivity; even when the habitat preference of the diatom species suggests a low lake level, the diatom-inferred conductivity is still very fresh. The reverse is also true in Lake Nyamogusingiri (ca. AD 19001950), when there is a large shift in the conductivity of the 
system, driven by the saline, planktonic taxon Thalassiosira rudolfi (conductivity optimum ca. $5700 \mu \mathrm{S} \mathrm{cm}^{-1}$; Mills and Ryves, 2012).

The discrepancy between the lake-level inference and DI conductivity may arise from three potential issues: (1) the conductivity optima of the main species included in the transfer function. Cyclotella meneghiniana is a problematic species in East Africa, with a broad conductivity tolerance (ca. $200 \mu \mathrm{S} \mathrm{cm}^{-1}$, Mills and Ryves, 2012, to $>10000 \mu \mathrm{S} \mathrm{cm}^{-1}$; European Diatom Database, Gasse et al., 1995), although its distribution in contemporary western Ugandan crater lakes results in a low optimum (the model applied here; see Mills and Ryves, 2012, for a full discussion), in agreement with observations from other East African lakes (e.g. Kilham, 1971). (2) The potential impact of regional groundwater hydrology in the crater lakes of western Uganda, where fresh groundwater and/or springs may feed the lakes during some periods of lower lake levels, coupled with the removal of salts via groundwater outflow, which keeps lake water fresh (see Ryves et al., 2011), perhaps particularly an issue in the shallower Lake Kyasanduka. (3) Conductivity may not be the primary controlling variable in the training set, and other variables may drive the diatom response (Juggins, 2013). This scenario is perhaps the likely source of error in these reconstructions, given that the change in salinity appears to be correlated with DCA axis 2 (Fig. 5a and $b$ ), and rather it is changes in diatom habitat preference that drive DCA axis 1 (Mills, 2009).

Lake Nyamogusingiri demonstrates a lake-level response for much of the record (driven by the fluctuating abundance of $N$. lancettula and C. meneghiniana), with a highstand following the MCA (ca. AD 1250-1340) and a higher lake level during the onset of the LIA (ca. AD 1500) which declines, suggesting a drying system throughout the remainder of the LIA (ca. AD 1600-1800). Lake levels in Lake Nyamogusingiri remain low until AD 1900, when the diatom habitat preference suggests a slight increase. However, this is the period (ca. AD 1900 to 1950) dominated by T. rudolfi, which is more indicative of saline waters (and therefore a lower lake level), even though it is a planktonic taxon (Gasse, 1986).

The inference of lake-level changes from the shallow Lake Kyasanduka is not straightforward, and diatom assemblages may actually be responding to a changing nutrient status in the system such as the $\mathrm{Si}: \mathrm{P}$ ratio (though indirectly linked to the lake level). At first, it appears that Lake Kyasanduka exhibits a dry lake system during the MCA, with aerophilous taxa dominating (e.g. N. seminulum and L. mutica). Levels stay low until ca. AD 1400, when there is a switch in the diatoms to an assemblage dominated by Aulacoseira spp., often interpreted as planktonic indicators of deeper water. While this could suggest an increase in the lake level which persisted throughout the LIA, this could only be to a maximum of $\sim 4 \mathrm{~m}$; moreover, other records from the region (and Lake Nyamogusingiri) suggest a drying trend. Given the small catchment-to-lake area $(\mathrm{CA}: \mathrm{L})$ ratio of Lake
Kyasanduka $(\sim 4)$ compared to that of Lake Nyamogusingiri ( $\geq 11.6$ ), Kyasanduka is likely to be less sensitive to catchment changes and more influenced by direct groundwater connections (e.g. allowing the lake to remain fresh via outflow of salts in drier periods), while Nyamogusingiri amplifies regional $\mathrm{P}: \mathrm{E}$ signals. It is therefore more plausible that the dominance of A. ambigua and A. granulata before (AD 1400) and during the LIA (ca. AD 1500-1800) is driven by turbidity under higher $\mathrm{Si}: \mathrm{P}$ during shallow conditions. Under low lake levels, wind mixing of the entire lake floor would effectively recycle Si from the bottom sediments, maintaining a high $\mathrm{Si}$ : P ratio (Kilham et al., 1986; Kilham and Kilham, 1990). It is unlikely that a shallow lake increased in depth when a deeper, neighbouring lake (and regional lake) system began to dry. The increase in sedimentderived turbidity in this system would also explain the reduction in benthic taxa during the LIA lowstand.

Lake-level reconstructions and habitat inferences from both systems should be treated with caution post AD 1800, as it seems that both lakes experience a large influx of catchment sediments (wetter climate coupled with human impacts; Fig. 5a and b) which dominates the ecological response of the diatoms. Whilst human impacts on vegetation in the region are known to span the last 1000-2000 years or more (Russell et al., 2009; Ryves et al., 2011; Gelorini and Verschuren, 2013), the effects on freshwater aquatic ecosystems (such as lakes Kyasanduka and Nyamogusingiri) are only apparent in the last 200 years (when the ecosystems likely cross a turbidity threshold).

\subsection{Drivers of diatom change over the last 1000 years}

To investigate the environmental factors that might be driving the changes in the aquatic environment, a set of predictor (e.g. $\Delta^{14} \mathrm{C}$, the Lake Pallcacocha ENSO record, regional lake levels; see Table S1, Supplement) and response (diatom taxa) variables was created. Constrained ordinations were carried out (i) to assess which of the specific predictors (drivers) go some way to quantitatively explaining the changes observed in the fossil diatom assemblage data, and (ii) to explore whether the data share similarities with other records of environmental change from across East Africa. The analyses highlight some of the main drivers behind the changes observed in the different records. The inclusion of other proxy lake-level data also helps to illustrate similarities between the various records. These similarities could be interpreted as either regional-scale events (e.g. MCA) or perhaps that the similar lake records share a similar driver (e.g. if similar to Lake Victoria levels, the lake may be responding to solar forcing). The full core CCA results are given in Table 2. The highlighted variables (Tables 3 and 4 ) are those that were selected as being statistically significant in "explaining" variation in the diatom data for each diatom zone (Bradshaw et al., 2005). 
The redundancy analysis suggests that different processes have influenced lake ecosystem response, and that change in the aquatic ecosystem has had different triggers through time. It should be noted that correlations are scale dependent: those demonstrated for diatoms and environmental variables on the century-millennial scale may not be the same as those observed on shorter timescales (Bradshaw and Anderson, 2003; Bradshaw et al., 2005). Where samples have high loadings with levels from other lake sequences, they may be linked to higher levels (e.g. Naivasha) at those sites; equally, samples at the opposite end of the vector are linked to lower inferred lake levels (e.g. Lake Kitigata). Where the records bear similarities to other records from across Uganda (e.g. Lake Kasenda), it can perhaps be inferred that the lake-level fluctuations are a regional signal, and where records bear similarities to the lake level from Lake Edward or Lake Naivasha, it may be an East African signal.

The full core CCA (Table 2) identifies general trends within the two data sets, and suggests that some of the general patterns observed are comparable to trends observed elsewhere in East Africa (e.g. Lake Edward and Lake Victoria/Nyamogusingiri), and such correlations may be interpreted as a response to a regional climatic or atmospheric driver (e.g. $\Delta^{14} \mathrm{C}$ ). The flux of organic and minerogenic sediments is also important for both core sequences, and this may account for the changes observed in the diatom assemblage data in the more recent past (post AD 1800).

The results of the RDA moving window illustrate shifts in the drivers of ecosystem change through time. The record from Lake Nyamogusingiri (Table 3), on a regional scale, suggests a link to $\Delta^{14} \mathrm{C}$ (a proxy for solar activity) and other systems in western Uganda (lakes Kitigata and Kasenda), suggesting some coherence of regional lake-level fluctuations in response to a large-scale atmospheric driver (e.g. solar forcing). Local drivers, which are based around the flux of organic and minerogenic sediments to the lake system, are also important, especially $\delta^{13} \mathrm{C}_{\mathrm{org}}$. It is likely that the link to $\delta^{13} \mathrm{C}_{\text {org }}$ (higher values; Mills, 2009) is a result of increasing aquatic productivity in the lake system.

Lake Kyasanduka has a record that bears similarity to a number of regional drivers (Table 4), with crater lakes Kitigata, Kibengo, and Kasenda and larger lakes Victoria and Naivasha being important regionally. Local drivers of changes in the diatom records are a result of the flux of minerogenic sediments and the delivery of organic sediments (or resuspension of nutrients from the lake bed) being important. Post AD 1850, Lake Kyasanduka shows changes that may be related to larger-scale drivers $\left(\Delta^{14} \mathrm{C}\right.$ and the Lake Pallcacocha ENSO record).

Redundancy analysis provides an insight into the data that would not be apparent in the direct comparison of the diatom-inferred lake (level) records to other published work (as shown in Fig. 6). The correlations alluded to here are complex, and may not be the result of a "cause and effect" relationship, yet they do reflect the general patterns of re-
Table 2. Results of CCA of the forward-selected (FS) environmental variables at Lake Nyamogusingiri and Lake Kyasanduka (last 1000 years) using the full data sets (all samples pre-AD 1975). The unique variance explained by each variable is also given. The $p$ value for all variables is 0.001 .

\begin{tabular}{|c|c|c|}
\hline FS variable & Canonical eigenvalue & $\%$ variance \\
\hline \multicolumn{3}{|c|}{ Lake Nyamogusingiri } \\
\hline All (6) & 0.385 & 26.37 \\
\hline Organic & 0.034 & 3.1 \\
\hline Mineral & 0.036 & 3.3 \\
\hline$\delta^{13} \mathrm{C}$ & 0.053 & 4.7 \\
\hline Victoria & 0.030 & 2.7 \\
\hline Kasenda & 0.039 & 3.5 \\
\hline Edward & 0.045 & 4.1 \\
\hline \multicolumn{3}{|c|}{ Lake Kyasanduka } \\
\hline All (6) & 0.676 & 36.7 \\
\hline Organic & 0.044 & 3.6 \\
\hline $\mathrm{CN}$ ratio & 0.061 & 5.0 \\
\hline Kitigata & 0.047 & 3.8 \\
\hline$\Delta^{14} \mathrm{C}$ & 0.042 & 3.5 \\
\hline Kibengo & 0.052 & 4.3 \\
\hline Edward & 0.035 & 2.9 \\
\hline
\end{tabular}

sponse of the diatom assemblages to various impacts on the lake ecosystem over time (Bradshaw et al., 2005), potential issues with the chronologies notwithstanding. The moving window RDA allows an understanding of changing drivers of ecosystem responses through time. Many of these drivers are contrasting, and not all are climate related. These analyses also indicate that drivers are not constant within a site or between sites, highlighting the potential issues in making direct climate inferences from proxies based on complex ecosystem processes. The differences in the limnological and catchment properties of the two lakes (relatively deep lake, large catchment - Nyamogusingiri - versus shallow lake, smaller catchment - Kyasanduka) are likely to filter signals of climate forcing in different ways (Magnuson et al., 2004; Leavitt et al., 2009). A lake's response to climate forcing is governed by factors such as its morphometry, chemistry, local hydrology (e.g. groundwater) and ecology. Lakes may amplify, attenuate, delay or extend the climate signal (Magnuson et al., 2004), so that the sedimentary records (i.e. diatom records in this study) are modified and are not simply a reflection of climate forcing.

In addition to this, whilst paired lakes might be expected to respond in tandem to a similar driver, complex interactions on the lake ecosystem scale, as a result of differing morphology, chemistry and CA:L will likely result in a different response in sedimentary diatom records. Therefore, where paired lakes do show a synchronous response, these are a direct result of a regional-scale forcing mechanism; other 
non-synchronous changes are likely to be much more local in scale.

\subsection{Coherence between records and regional comparison}

The sediment sequences presented here were taken from a paired lake system located on the Rift Valley floor, within Queen Elizabeth National Park. As these neighbouring lakes share a similar geology, vegetation, climate and recent human impact, our initial hypothesis is that the patterns (trajectories) of lake response (here, using diatom assemblages as the proxy) would be similar if these factors are important drivers of lake and catchment change (modulated by lakespecific characteristics).

Whilst the two lakes differ in their hydrology (i.e. CA : L), diatom assemblages and, therefore, ecological response, there is coherence in terms of the diatom trajectories in both systems, as summarised by their DCA axis 1 sample scores (Fig. 7). Both systems show a steady decline in their DCA values from ca. AD 1100 to ca. AD 1870, at which point the DCA sample scores reach their lowest point. The sample scores remain low until the late 1990s, after which they rise towards the present day. The correlation between the two records suggests that there is a common diatom response even if the relationship is complex and the result of multiple interacting drivers (i.e. climate, hydrology and human impact). These interactions and the resulting complexity in the diatom archives can make interpretation of the records complicated, and might only be resolved with the analysis of more lakes and detailed, contemporary ecological information.

Statistical zoning of the diatom data also shows a number of coherent "time" zones (Figs. $4 \mathrm{a}$ and $4 \mathrm{c}$, and $6 \mathrm{j}$ and $6 \mathrm{k}$ ). These chronozones common to both cores occur at ca. AD 1400, ca. AD 1550-1600 and ca. AD 1850-1900. By directly comparing a range of lake-level records from across East Africa, together with inferred lake-level curves from lakes Nyamogusingiri and Kyasanduka (Fig. 6), the spatial and temporal (dis)similarities of lake-level responses to climate drivers can be observed.

There is some indication that, prior to AD 1200, the climate in eastern and central Africa showed a transition to drier conditions, which likely began earlier during the middle to late Holocene (Verschuren and Charman, 2008). The larger lakes Edward and Victoria both indicate a drier period, punctuated with fresh episodes, although smaller lakes (e.g. Kasenda and Kitigata) appear to exhibit wetter conditions, which may indicate a complex pattern of lake response during the MCA. However, the ecological preference of the fossil diatoms in Lake Kasenda suggest that the lake was more likely to be shallow at this time, and it is likely that groundwater helped to keep this system fresh (Ryves et al., 2011). The diatom-inferred lake levels from lakes Nyamogusingiri and Kyasanduka record a period of aridity at the onset of the 2nd millennium (AD 1000-1200). The evidence for this arid phase is evident elsewhere in East Africa, in the records from Ethiopia (Lake Hayq, Lamb et al., 2007) and Kenya (Naivasha, Verschuren et al., 2000), and from AD 1000 to AD 1200, historical summer Nilometer readings were at a minimum (Nicholson, 1998), coincident with the MCA.

The lowstand of ca. AD 1100 in lakes Nyamogusingiri and Kyasanduka persisted until the mid-13th century in Nyamogusingiri and as late as AD 1400 in Kyasanduka. Lake Naivasha provides evidence that this arid phase was punctuated by a freshwater event in the early 13th century (Verschuren et al., 2000). A similar event is observed a little later in Lake Edward (Russell and Johnson, 2007), ca. AD 1250; this is also mirrored in Lake Nyamousingiri, with a return to fresh, deep conditions. This event could be the result of a regional climatic perturbation.

East African records from larger lakes (Naivasha, Malawi, Turkana, Tanganyika, Victoria) suggest a return to wetter conditions and higher lake levels from the end of the 13th century and into the 14th century (Verschuren, 2004); however, both Nyamogusingiri and Kyasanduka suggest lower levels. During this period, both systems are dominated by benthic taxa, which may be interpreted as a lower lake level. Conversely, lake levels could be increasing in these systems: clear water would encourage macrophyte growth and stabilise the sediment, creating more available habitat for benthic (periphytic) species. From AD 1350, Lake Nyamogusingiri suggests a steadily increasing lake level, and the shallow Lake Kyasanduka suggests an increase in lake level in ca. AD 1400.

At the onset of the LIA (ca. AD 1500), both lakes suggest a period of a higher lake level. In the deeper Nyamogusingiri, the lake level declines (from ca. AD 1500) throughout the LIA; conversely, the shallow Kyasanduka levels remain relatively high. It is unlikely that such a shallow system would increase in level during the LIA, especially when regional lake systems (e.g. Lake Edward, Lake Kibengo and Lake Victoria) all show a similar drying trend to that observed in Nyamogusingiri. It is therefore likely that the diatoms from Lake Kyasanduka are responding to shifts in nutrient availability and turbidity in a very shallow system (see Sect. 5.1). During this period, lake levels at Tanganyika fell to their lowest levels and did not recover until the late 1800s. Similarly, Lake Chad water levels were high in ca. AD 1100 and AD 1600 , with lower levels during the 15th to 16th centuries (as reviewed in Verschuren, 2004 and Maley, 2010). These results support an anti-phase in terms of lake level between East Africa (e.g. Lake Naivasha) and central and southern East Africa, and where lake levels were much lower at this time (e.g. lakes Kibengo, Edward, and Nyamogusingiri; Russell and Johnson, 2007; Russell et al., 2007; Tierney et al., 2013).

It has been suggested that higher lake levels occur in response to rising atmospheric $\Delta^{14} \mathrm{C}$ residual series (a proxy for solar activity; Stuiver and Braziunas, 1989). Stager et 
Table 3. Results of the moving window RDA from Lake Nyamogusingiri. The variance explained is a percentage of the constrained variance. The shaded boxes highlight the most statistically significant driver(s) correlated with a change in the diatom stratigraphy in each of the age groupings.

\begin{tabular}{|c|c|c|c|c|c|c|c|c|c|c|c|c|c|c|c|}
\hline \multirow[b]{2}{*}{ Zone } & \multirow[b]{2}{*}{ Year AD } & \multicolumn{5}{|c|}{ Local } & \multicolumn{8}{|c|}{ Regional } & \multirow{2}{*}{$\begin{array}{c}\% \\
\text { explained }\end{array}$} \\
\hline & & DMAR & Organic & Minerogenic & $\delta^{13} \mathrm{C}_{\text {org }}$ & $\mathrm{C} / \mathrm{N}$ & Pallcacocha & $\Delta^{14} \mathrm{C}$ & Naivasha & Edward & Victoria & Kibengo & Kitigata & Kasenda & \\
\hline 1 & $1150-1250$ & $\mathrm{X}$ & & & $\mathrm{X}$ & & & $\mathrm{X}$ & & & & & & & 35.1 \\
\hline 2 & $1250-1300$ & & & & & & & $\mathrm{X}$ & & & & & & & 27.9 \\
\hline 3 & $1300-1400$ & & & & $\mathrm{X}$ & & & & & & & & $\mathrm{X}$ & $\mathrm{X}$ & 19.4 \\
\hline 4 & $1400-1650$ & & & & & & & & & & & & & & $\mathrm{n} / \mathrm{a}$ \\
\hline 5 & $1650-1900$ & & & & $\mathrm{X}$ & & & $\mathrm{X}$ & & & & & & $\mathrm{X}$ & 40.6 \\
\hline $6 a$ & $1900-1975$ & & & & & & & & $\mathrm{X}$ & & & & & $\mathrm{X}$ & 29.5 \\
\hline $6 b^{*}$ & $1975-2000$ & & & & $\mathrm{X}$ & & & & & & & & & & 16.9 \\
\hline
\end{tabular}

* This zone (AD 1975-2000) was run with a reduced set of "predictor" variables (Lakes Naivasha, Edward and Victoria were not included; see Sect. 3.3.2 for details).

Table 4. Results of the moving window RDA from Lake Kyasanduka. The variance explained is a percentage of the constrained variance. The shaded boxes highlight the most statistically significant driver(s) correlated with a change in the diatom stratigraphy in each of the age groupings.

\begin{tabular}{|c|c|c|c|c|c|c|c|c|c|c|c|c|c|c|c|}
\hline \multirow[b]{2}{*}{ Zone } & \multirow[b]{2}{*}{ Year AD } & \multicolumn{5}{|c|}{ Local } & \multicolumn{8}{|c|}{ Regional } & \multirow[t]{2}{*}{$\%$ explained } \\
\hline & & DMAR & Organic & Minerogenic & $\delta^{13} \mathrm{C}_{\mathrm{org}}$ & $\mathrm{C} / \mathrm{N}$ & Pallcacocha & $\Delta^{14} \mathrm{C}$ & Naivasha & Edward & Victoria & Kibengo & Kitigata & Kasenda & \\
\hline 1 & $1050-1150$ & & & & & & & & & & & $\mathrm{X}$ & & & 18.5 \\
\hline 2 & $1150-1400$ & & & $\mathrm{X}$ & $\mathrm{X}$ & $\mathrm{X}$ & & & & & & & & & 17.1 \\
\hline 3 & $1400-1600$ & & & & & & & & $\mathrm{X}$ & & & $\mathrm{x}$ & & & 14.9 \\
\hline 4 & $1600-1750$ & & & & & & & & & & $\mathrm{x}$ & & $\mathrm{X}$ & & 20.2 \\
\hline 5 & $1750-1850$ & & $\mathrm{X}$ & & & & & & & & & & & $\mathrm{X}$ & 28.1 \\
\hline $6 a$ & $1850-1975$ & & $\mathrm{X}$ & & & & $\mathrm{X}$ & & & & & & & & 5.6 \\
\hline $6 b^{*}$ & $1975-2000$ & & & & & & & $\mathrm{X}$ & & & & & & & 6.9 \\
\hline
\end{tabular}

* This zone (AD 1975-2000) was run with a reduced set of "predictor" variables (Lakes Naivasha, Edward and Victoria were not included; see Sect. 3.3.2 for details).

al. (2007) suggest that changes in solar activity (sunspot numbers) are transmitted to lake systems through changes in rainfall activity: with higher lake levels associated with increased rainfall during periods of decreased sunspot numbers. This correlation is significant throughout the 20th century (Stager et al., 2007), and it is thought that the increased solar activity serves to enhance small thermal effects on surface water bodies (and likely tropical SSTs) by increasing humidity, and therefore influences East African precipitation through changes in the ITCZ. $\Delta^{14} \mathrm{C}$ rose during the Wolf (AD 1280-1350), Spörer (AD 1416-1534) and Maunder sunspot minima (AD 1645-1715; Nesje and Dahl, 2000); the earlier changes in $\Delta^{14} \mathrm{C}$, broadly correspond to the higher lake levels at Nyamogusingiri; lake levels are low in this system during the Maunder minimum. A similar drying response is observed in Lake Edward (Russell and Johnson, 2007), even though other systems in Uganda (e.g. Lake Victoria and Lake Kasenda) suggest higher lake levels (as does Lake Naivasha).

There is evidence from Lake Victoria that this relationship between sunspot minima and higher lake levels reversed during the late 19th and early 20th centuries (AD 1890-1927), coincident with the Dalton sunspot minimum (AD 17901820; Stager et al., 2005). This reversal caused low lake levels to occur coincident with the Dalton minimum. Lake Nyamogusingiri suggests a lower lake level at this time. Lake Kyasanduka remained shallow, probably for the entire record (given that the lake could not have reached depths greater than $3 \mathrm{~m}$ ), with assemblage changes a response to nutrient availability, specifically Si : P ratios (Kilham et al., 1986; Kilham and Kilham, 1990).

At the end of the LIA (ca. AD 1700-1750), lake levels in Uganda and elsewhere in East Africa suggest a return to wetter conditions (lakes Edward, Victoria, Kasenda, Naivasha and Lake Abiyata; Legesse et al., 2004), though this is not immediately obvious in the lake-level reconstruction from Nyamogusingiri. The dominant taxon at this time (N. lancettula) does suggest an increase in lake level at this time. It is likely that wet conditions in ca. AD 1750 were confined to a narrow belt along the equatorial region of East Africa. This is further supported by inferred drought at Lake Malawi (Brown and Johnson, 2005) and Lake Tanganyika (Cohen et al., 2005), further south, at the same time.

Towards the end of the 18th century and the beginning of the 19th century, there is widespread evidence of drought conditions across East Africa (Nicholson, 1995, 1998; Verschuren et al., 2000; Stager et al., 2005; Bessems et al., 2008; Ryves et al., 2011; Fig. 6). Lake levels in Nyamogusingiri appear to fall, the abundance of $N$. lancettula drops over this period, and benthic/periphytic taxa increase, together with the appearance of Thalassiosira rudolfi (Figs. 4a, 5a and 6), but it is a more subtle change. This implies that the deep basin remained connected to the main lake over this time, as it did throughout the LIA period (Fig. 4a). 




Figure 7. Comparison of DCA axis 1 sample scores from Lake Nyamogusingiri and Lake Kyasanduka.

From the late 19th century, written records and observations can supplement palaeolimnological data (Endfield et al., 2009). There is documentary evidence of a dry period in ca. AD 1890s, and also evidence of low lake levels in Lake Victoria (Nicholson, 1998). The lake level at Nyamogusingiri is low, but appears to fluctuate from AD 1890 onwards. However, this period also signals the onset of significant human impacts on the two lake systems, and this signal may simply overprint records of hydrological forcing.

Increasing human impacts are evident over the last 150 200 years, with an increase in the delivery of organic matter to the lake ecosystems (Fig. 5a and b), likely driven by changes in catchment vegetation (and subsequently catchment hydrology). It is therefore likely that some responses observed in the diatom records are driven by nutrients and turbidity, rather than as a result of climate changes and fluctuating lake levels (Battarbee, 2000; Becht and Harper, 2002;
Verschuren et al., 2002; Legesse et al., 2003, 2004; Cohen et al., 2005; Plater et al., 2006). The drought of the 1940s to 1950 s is clearly seen at Nyamogusingiri, where a drop in $N$. lancettula is followed by a rise in $N$. palea, C. meneghiniana, and finally T. rudolfi (Fig. 4b), and by a peak in DI conductivity. This is less clear at Kyasanduka, although the sudden drop in F. microrhombus and rise in N. bacata (together with a marked drop in the diatom concentration) implies some sudden but short-lived change to diatom communities that may be linked to this, although DI conductivity at this lake shows no change. This likely represents the arid event of the 1940s and 1950s, seen across East Africa (e.g. Verschuren, 2001). Most likely, a drop in the lake level caused the smaller, deeper basin to separate from the main lake (the level falling below the sill) and to operate as a closed system, which may have also amplified the evaporative salinity signal if salts, concentrated by direct evaporation from the lake surface, were not removed by groundwater exchange (Mills, 2009), which we speculate happens when it is connected to the main basin.

During fieldwork in 2007, local people recounted tales from elders of times when the deeper basin was isolated. This event may well have been responsible for the establishment of the (now submerged) mature trees around the margin of the lake (rooted at $2 \mathrm{~m}$ in water depth) that were killed following a later lake-level rise, which also reconnected the smaller crater to the larger Lake Nyamogusingiri basin (as observed at the time of this research). It is unclear why this drought period would cause the lake level to fall below the sill when it apparently did not happen over the preceding several hundred years (including the dry LIA). It may be that local/regional hydrology or catchment hydrological connectivity has altered over time, allowing the lake level to fall to the critical threshold at which the deep basin became isolated across the sill.

\section{Regional drivers}

Equatorial East Africa has a complex regional patchwork of climate regimes, with a general eastward trend of increasing aridity. Over long timescales, there are multiple interacting drivers that appear to have a causal relationship with longterm trends in rainfall and lake levels. The causes of centuryto millennial-scale climate variability in tropical Africa and the drivers of some of the significant climatic perturbations (e.g. MCA and LIA) are poorly understood (Russell and Johnson, 2005).

Widespread drought conditions in ca. AD 1200, coincident with the MCA, affected much of East Africa (Verschuren et al., 2000; Verschuren, 2004; Russell and Johnson, 2005; Russell et al., 2007; this study). The arid conditions have been linked to a period of increased solar activity (Fig. 6) and, potentially, changes in the North Atlantic thermohaline circulation (Broecker et al., 1999). More recently, evidence has been presented of a more complex MCA, with wetter events 
punctuating the generally drier conditions. Whether this is interpreted as regional complexity during the MCA, or whether the differences arise from the proxies used or chronological uncertainties, is questionable.

The recording of the LIA in sedimentary proxies from East African lakes appears to be more complex, with increasing evidence of a climatic gradient during this time (Russell et al., 2007). Russell et al. (2007) suggest that AD 1500 marked the onset of arid conditions in western Uganda. The results from this study go some way to corroborating the hypothesis of Russell et al. (2007), and suggest common anti-phasing between western sites (Kibengo, Kitagata, Edward, Tanganyika, Nyamogusingiri and Kyasanduka) and sites from eastern equatorial Africa (Naivasha and Victoria; Russell et al., 2007). This may support the existence of an east-west gradient in which wet conditions in eastern equatorial East Africa were synchronous with arid conditions in western equatorial East Africa (Russell et al., 2007; Tierney et al., 2013).

The patterns of climate variability across East Africa and their links to changes at higher latitudes is a question that still remains to be resolved (Barker and Gasse, 2003; Brown and Johnson, 2005; Russell and Johnson, 2005a, b). It has been suggested that mechanisms controlling rainfall anomalies during the LIA are unlike those occurring during the last 100 years (Nicholson, 1986). The southward migration of the ITCZ in response to cooling at higher latitudes is often cited as the main hypothesis for explaining the changes during the LIA (Baker et al., 2001; Haug et al., 2001; Brown and Johnson, 2005; Russell and Johnson, 2005a; Russell et al., 2007). However, changes in the Indian Ocean dipole (IOD; Marchant et al., 2006) coupled with ENSO may be the cause of high rainfall anomalies (Nicholson et al., 1997). In addition to this, lake-level fluctuations in Lake Victoria have long been linked to sunspots (Brooks, 1923; Stager et al., 2005); however, the inconsistency of sun-rainfall associations (e.g. during the Dalton minimum) brings this proposed relationship into question (Stager et al., 2005), unless sun-climate relationships in East Africa are subject to abrupt variability.

Russell and Johnson (2007) suggest that it is ENSO which is the key factor linking high-latitude cooling, the ITCZ, and moisture gradients within Africa, and models suggest that increased insolation in the Southern Hemisphere and southward migration of the ITCZ are associated with more intense ENSO years (Haug et al., 2001; Moy et al., 2002). Russell and Johnson (2007) suggest that it is therefore possible that interactions between the ITCZ and the ENSO system during the LIA may have triggered a shift toward El Niño-like conditions, increasing rainfall in easternmost Africa, while southward ITCZ migration led to increased aridity in the west.

\section{Conclusions}

The sedimentary archives of diatom assemblages, dated using ${ }^{210} \mathrm{~Pb},{ }^{137} \mathrm{Cs}$ and ${ }^{14} \mathrm{C}$, from two Ugandan crater lakes provide high-resolution, annual to sub-decadal records of lake-level fluctuations during the last 1000 years. Despite the limnological variations between the two lake systems (e.g. depth, CA : L), reconstructed lake levels and independent statistical analyses (DCA, RDA) indicate a regional coherence within these sediment archives, with the lakes responding similarly to external drivers through time. Furthermore, statistical analyses and the comparison of these archives to previous palaeolimnological work in Uganda and across East Africa suggest that the western Uganda crater lakes are sensitive to climatic perturbations such as a major arid phase coincident with the northern hemispheric MCA (AD 10001200 ) and a drying trend during the LIA main phase (AD 1600-1800), though the latter is also characterised by fluctuating lake levels. The general trends support the hypothesis of an east-west (wet-dry) gradient across East Africa during the LIA. However, the relationship is more complex towards the end of the LIA (ca. AD 1700-1800), when it appears that cultural disturbances within the catchment (causing increases in sediment and nutrient flux) dominate and mask the climate signals preserved within these systems.

It may be expected that paired (neighbouring) lakes will respond in a similar fashion to the same driving force; where observed changes are synchronous, these are interpreted as a climate signal. However, lakes Nyamogusingiri and Kyasanduka appear to operate as independent systems in their recording of a similar hydrological response signal via a distinct local diatom record. Whether such an outcome is problematic will depend on the approach used in the understanding of lake sedimentary archives. This research highlights the importance of avoiding single lake studies as an archive of regional environmental change, and the complexities when comparing neighbouring lake systems, highlighting the contribution of intrinsic lake mechanisms to external drivers, which is difficult to quantify. It is critical that any approach to climate reconstructions from lake sediments, especially those pertaining to biological proxies, accounts for the multi-proxy aspect of diatom response to environmental forcing and climate effects when they exist (i.e. can be seen or are recorded in the sediment archive), and are still filtered through the catchment and modified by the lake itself.

Taken together, the data show the communality but also complexity of individual and paired lake responses to climate forcing, and hence how such studies should be treated with caution. This research also highlights the importance of natural high-density lake districts, such as western Uganda, where more than 80 lakes form clusters that share a similar geology, climate and landscape, while the clusters themselves are dispersed along gradients of effective moisture, vegetation and human impact. A comprehensive understanding of the functioning of these present-day lake systems is 
critical to understanding past responses to climate and human disturbance, especially as this landscape of lakes forms a natural laboratory in which to test, and understand, environmental forcing and ecosystem response from the local to the regional scale.

\section{The Supplement related to this article is available online at doi:10.5194/cp-10-1581-2014-supplement.}

Acknowledgements. This work was completed by KM as part of a Ph.D. carried out at and funded by Loughborough University. Financial support for the fieldwork was provided through NERC (UK) within a New Investigators' Competition award (NE/D000157/1) to DBR. Radiocarbon dating was supported by NERC Radiocarbon Facility NRCF010001 (allocation numbers 1233.0407 and 1264.1007). Peter Appleby is acknowledged for his assistance with $\mathrm{Pb}-210$ dating and Christine Cocquyt thanked for her diatom taxonomic assistance. We thank the Uganda National Council for Science and Technology (permit EC482), the Uganda Wildlife Authority and the Office of the President for fieldwork permission. Sincere thanks go to Sergi Pla and Richard Nyakoojo for their invaluable help in the field. The diatom and radiocarbon data from this research have been lodged with NOAA-NCDC, and can be accessed via (DATA CURRENTLY UNDER REVIEW - http://hurricane.ncdc.noaa.gov/pls/paleox/f?p=519:1:0:::: P1_STUDY_ID:16791).

Edited by: M. E. de Porras

\section{References}

Appleby, P. G.: Chronostratigraphic techniques in recent sediments, in: Tracking Environmental Change Using Lake Sediments Volume 1: Basin Analysis, Coring, and Chronological Techniques, edited by: Last, W. M. and Smol, J. P., Springer, Netherlands, 171-203, 2001.

Baker, P. A., Seltzer, G. O., Fritz, S. C., Dunbar, R. B., Grove, M. J., Tapia, P. M., Cross, S. L., Rowe, H. D., and Broda, J. P.: The History of South American Tropical Precipitation for the Past 25,000 Years, Science, 291, 640-643, 2001.

Barker, P. and Gasse, F.: New evidence for a reduced water balance in East Africa during the Last Glacial Maximum: implication for model-data comparison, Quat. Sci. Rev., 22, 823-837, 2003.

Barker, P., Telford, R., Gasse, F., and Thevenon, F.: Late Pleistocene and Holocene palaeohydrology of Lake Rukwa, Tanzania, inferred from diatom analysis, Palaeogeogr. Palaeoclimatol. Palaeoecol., 187, 295-305, 2002.

Battarbee, R. W.: Palaeolimnolgical approaches to climate change, with special regard to the biological record, Quat. Sci. Rev., 19, 107-204, 2000.

Battarbee, R. W. and Kneen, M. J.: The use of electronically counted microspheres in absolute diatom analysis, Limnol. Oceanogr., 27, 184-188, 1982.
Becht, R. and Harper, D. M.: Towards an understanding of human impact upon the hydrology of Lake Naivasha, Kenya, Hydrobiologia, 488, 1-11, 2002.

Bessems, I., Verschuren, D., Russell, J. M., Hus, J., Mees, F., and Cumming, B. F.: Palaeolimnological evidence for widespread late 18th century drought across equatorial East Africa, Palaeogeog. Palaeoclimatol. Palaeoecol., 259, 107-120, 2008.

Birks, H. J. B. and Gordon, A. D.: Numerical methods in Quaternary Pollen Analysis, Academic Press, London, 317 pp., 1985.

Blaauw, M.: Methods and code for 'classical' age-modelling of radiocarbon sequences, Quat. Geochronol., 5, 512-518, 2010.

Bradshaw, E. G. and Anderson, N. J.: Environmental factors that control the abundance of Cyclostephanos dubius (Bacillariophyceae) in Danish lakes, from seasonal to century scale, Eur. J. Phycol., 38, 265-276, 2003.

Bradshaw, E. G., Rasmussen, P., and Odgaard, B. V.: Mid- to lateHolocene land-use change and lake development at Dallund S $\varnothing$, Denmark: synthesis of multiproxy data, linking land and lake, Holocene, 15, 1152-1162, 2005.

Broecker, W. S., Sutherland, S., and Peng, T.-H.: A possible 20thcentury slowdown of Southern Ocean deep water formation, Science, 286, 1132-1135, 1999.

Brooks, C. E. P.: Variations in the levels of the central African lakes Victoria and Albert, Geophysical Memoirs, 20, 337-344, 1923.

Brown, E. T. and Johnson, T. C.: Coherence between tropical East Africa and South American records of the Little Ice Age, Geochem. Geophys. Geosys., 6, 1-11, 2005.

Chalié, F. and Gasse, F.: Late Glacial-Holocene diatom record of water chemistry and lake level change from the tropical East African Rift Lake Abiyata (Ethiopia), Palaeogeogr. Palaeoclimatol. Palaeoecol., 187, 259-283, 2002.

Charles, D. F., Acker, F. W., Hart, D. D., Reimer, C. W., and Cotter, P. B.: Large-scale regional variation in diatom-water chemistry relationships: rivers of the eastern United States, Hydrobiologia, 561, 27-57, 2006.

Cholnoky, B. J.: Bacillariophyceae from the Bangweulu Swamps. Cercle Hydrobiologique de Bruxelles, Brussels, 71 pp., 1970.

Cocquyt, C.: Diatoms from the Northern Basin of Lake Tanganyika. Bibliotheca Diatomologica 39, Crammer, Berlin/Stuttgart, 274 pp., 1998.

Cohen, A. S., Palacios-Fest, M. R., Msaky, E. S., Alin, S. R., McKee, B., O'Reilly, C. M., Dettman, D. L., Nkotagu, H., and Lezzar, K. E.: Paleolimnological investigations of anthropogenic environmental change in Lake Tanganyika: IX. Summary of paleorecords of environmental change and catchment deforestation at Lake Tanganyika and impacts on the Lake Tanganyika ecosystem, J. Paleolimnol., 34, 125-145, 2005.

Conway, D.: Extreme Rainfall Events and Lake Level Changes in East Africa: Recent Events and Historical Precedents, in: The East African Great Lakes: Limnology, Palaeolimnology and Biodiversity, edited by: Odada, E. O. and Olago, D. O., Springer, Netherlands, 588 pp., 2002.

Dean Jr., W. E.: Determination of carbonate and organic matter in calcareous sediments and sedimentary rocks by loss on ignition: Comparison with other methods, Journal of Sedimentary Petrology, 44, 242-248, 1974.

Doyle, S.: Crisis and Decline in Bunyoro: Population and Environment in Western Uganda 1860-1955, Ohio University Press, 320 pp., 2006. 
European Diatom Database (EDDI): http://craticula.ncl.ac.uk/ Eddi/, last access: 9 August 2013.

Endfield, G., Ryves, D. B., Mills, K., and Berrang-Ford, L.: "The gloomy forebodings of this dread disease": climate, environment and sleeping sickness in East Africa around the turn of the twentieth century, Geographical Journal, 175, 181-195, 2009.

Fritz, S. C., Juggins, S., and Battarbee, R. W.: Diatom assemblages and ionic characterization of lakes of the Great Northern Plains, North America: a tool for reconstructing past salinity and climate fluctuations, Can. J Fish. Aquat. Sci., 50, 1844-1856, 1993.

Gasse, F.: East African diatoms; Taxonomy, ecological distribution, Bibliotheca Diatomologica 11, Crammer, Berlin/Stuttgart, 201 pp., 1986.

Gasse, F., Juggins, S., and Ben Khelifa, L.: Diatom-based transfer functions for inferring past hydrochemical characteristics of African lakes, Palaeogeogr. Palaeoclimatol. Palaeoecol., 117, 31-54, 1995.

Gasse, F., Barker, P., Gell, P. A., Fritz, S. C., and Chalié, F.: Diatominferred salinity in palaeolakes: An indirect tracer of climate change, Quat. Sci. Rev., 16, 547-563, 1997.

Gelorini, V. and Verschuren, D.: Historical climate-humanecosystem interaction in East Africa: a review, Afr. J. Ecol., 51, 409-421, 2013.

Haug, G. H., Hughen, K. A., Sigman, D. M., Peterson, L. C., and Röhl, U.: Southward migration of the intertropical convergence zone through the Holocene, Science, 293, 1304-1307, 2001.

Hill, M. O. and Gauch, H. G.: Detrended correspondence analysis: An improved ordination technique, Plant Ecol., 42, 47-58, 1980.

Juggins, S.: ZONE: a DOS program for the zonation (constrained clustering) of palaeoecological data, Newcastle University, 2002.

Juggins, S.: Quantitative reconstructions in palaeolimnology: new paradigm or sick science?, Quat. Sci. Rev., 64, 20-32, 2013.

Kilham, P.: Biogeochemistry of African lakes and rivers. Ph. D. thesis, Duke University, 199 pp., 1971.

Kilham, P. and Kilham, S. S.: Endless summer: internal loading processes dominate nutrient cycling in tropical lakes, Freshw. Biol., 23, 379-389, 1990.

Kilham, P., Kilham, S. S., and Hecky, R. E.: Hypothesized resource relationships among African planktonic diatoms, Limnol. Oceanogr., 31, 1169-1181, 1986.

Krammer, K. and Lange-Bertalot, H.: Bacillariophyceae. 1. Teil. Naviculaceae. Süßwasserflora von Mitteleuropa, Band 2/1, Verlag, Stuttgart, 876 pp., 1986.

Krammer, K. and Lange-Bertalot, H.: Bacillariophyceae. 2. Teil. Bacillariaceae, Epithemiaceae, Surirellaceae. Süßwasserflora von Mitteleuropa, Band 2/2, Verlag, 596 pp., Stuttgart, 1988.

Krammer, K. and Lange-Bertalot, H.: Bacillariophyceae. 3. Teil. Centrales, Fragilariaceae, Eunotiaceae. Süßwasserflora von Mitteleuropa, Band 2/3, Verlag Stuttgart, 600 pp., 1991a.

Krammer, K. and Lange-Bertalot, H.: Bacillariophyceae. 4. Teil. Achnanthaceae, kritsche erganzungen zu Navicula (Lineolatae) und Gomphonema Gesamliteraturverzeichnis. Süßwasserflora von Mitteleuropa, Band 2/4, Verlag Stuttgart, 437 pp., $1991 \mathrm{~b}$.

Lamb, H. F., Leng, M. J., Telford, R. J., Ayenew, T., and Umer, M.: Oxygen and carbon isotope composition of authigenic carbonate from an Ethiopian lake: a climate record of the last 200 years, Holocene, 17, 517-526, 2007.
Langdale-Brown, I., Osmaston, H. A., and Wilson, J. G.: The Vegetation of Uganda and Its Bearing on Land-Use, Govt, Uganda, Entebbe, 1964.

Lange-Bertalot, H.: Pollution tolerance of diatoms as a criterion for water quality estimation, Nova Hedwigia, 64, 285-305, 1979.

Leavitt, P. R., Fritz, S. C., Anderson, N. J., Baker, P. A., Blenckner, T., Bunting, L., Catalan, J., Conley, D. J., Hobbs, W. O., Jeppesen, E., Korhola, A., McGowan, S., Rühland, K., Rusak, J. A., Simpson, G. L., Solovieva, N., and Werne, J.: Paleolimnological evidence of the effects on lakes of energy and mass transfer from climate and humans, Limnol. Oceanogr., 54, 2330-2348, 2009.

Legesse, D., Vallet-Coulomb, C., and Gasse, F.: Hydrological response of a catchment to climate and land use changes in Tropical Africa: case study South Central Ethiopia, J. Hydrol., 275, 67-85, 2003.

Legesse, D., Vallet-Coulomb, C., and Gasse, F.: Analysis of the hydrological response of a tropical terminal lake, Lake Abiyata (Main Ethiopian Rift Valley) to changes in climate and human activities, Hydrol. Process., 18, 487-504, 2004.

Leland, H. V. and Porter, S. D.: Distribution of benthic algae in the upper Illinois River basin in relation to geology and land use, Freshw. Biol., 44, 279-301, 2000.

Leps, J. and Šmilauer, P.: Multivariate Analysis of Ecological data using CANOCO, Cambridge University Press, Cambridge, 282 pp., 2003.

Lock, J. M.: Vegetation in relation to grazing and soils in Queen Elizabeth National Park. Ph. D. thesis, Cambridge University, Cambridge, 1967.

Magnuson, J. J., Benson, B. J., and Kratz, T. K.: Patterns of coherent dynamics within and between lake districts at local to intercontinental scales, Boreal Environ. Res., 9, 359-369, 2004.

Maley, J.: Climate and palaeoenvironment evolution in north tropical Africa from the end of the Tertiary to the Upper Quaternary, Palaeoecology of Africa, 30, 227-278, 2010.

Marchant, R., Mumbi, C., Behera, S., and Yamagata, T.: The Indian Ocean dipole - the unsung driver of climatic variability in East Africa, Afr. J. Ecol., 45, 4-16, 2006.

Melack, J. M.: Morphometric, physical and chemical features of the volcanic crater lakes of western Uganda, Arch. Hydrobiol., 84, 430-453, 1978.

Mills, K.: Ugandan Crater Lakes: Limnology, Palaeolimnology and Palaeoenvironmental History. Ph. D. thesis, Loughborough University, 429 pp., available at: https://dspace.lboro.ac.uk/2134/ 13219, 2009.

Mills, K. and Ryves, D. B.: Diatom-based models for inferring past water chemistry in western Ugandan crater lakes, J. Paleolimnol., 48, 383-399, 2012.

Moy, C. M., Seltzer, G., Rodbell, D. T., and Anderson, D. M.: Variability of El Niño/Southern Oscillation activity at millennial timescales during the Holocene epoch, Nature, 404, 162-165, 2002.

Nesje, A. and Dahl, S. O.: Glaciers and Environmental Change, Arnold, London, 216 pp., 2000.

Nicholson, S. E.: The spatial coherence of African rainfall anomalies: interhemispheric teleconnections, J. Climatol. Appl. Meteorol., 25, 13651-13681, 1986.

Nicholson, S. E.: Variability of African rainfall on interannual and decadal time scales, in: Natural Climate Variability on Decade- 
to-Century Time Scales, edited by: Climate Research committee, National Academy Press, Washington, 630 pp., 1995.

Nicholson, S. E.: Environmental change within the historical period, in: The physical geography of Africa, edited by: Adams W. M., Goudie A. S. and Orme A. R., Oxford University Press, Oxford, 1996.

Nicholson, S. E.: Historical fluctuations of Lake Victoria and other lakes in the Northern Rift Valley of East Africa, in: Environmental Change and Response in East African Lakes, edited by: Lehman, J. T., Springer, Netherlands, 236 pp., 1998.

Nicholson, S. E.: The nature of rainfall variability over Africa on time scales of decades to millennia, Global Planet. Change, 26, 137-158, 2000.

Nicholson, S. E. and Yin, X.: Rainfall conditions in equatorial East Africa during the Nineteenth Century as inferred from the record of Lake Victoria, Clim. Change, 48, 387-398, 2001.

Nicholson, S. E., Kim, J., and Ba, M. B.: The mean surface water balance over Africa and its interannual variability, J. Climate, 10, 2981-3002, 1997.

Nicholson, S. E., Nash, D. J., Chase, B. M., Grab, S. W., Shanahan, T. M., Verschuren, D., Asrat, A., Lézine, A,-M., and Umer, M.: Temperature variability over Africa during the last 2000 years, Holocene, 23, 1875-1887, doi:10.1177/0959683613483618, 2013.

Odgaard, B. V.: The Holocene vegetation development history of northern West Jutland, Denmark, Opera Botanica, 123, 1-171, 1994.

Owen, R. B. and Crossley, R.: Spatial and temporal distribution of diatoms in sediments of Lake Malawi, Central Africa, and ecological implications, J. Paleolimnol., 7, 55-71, 1992.

Patrick, R. and Reimer, C. W.: The diatoms of the United States, Vol. 1, Monographs of the Academy of Natural Sciences of Philadelphia, Number 13, 1966.

Patrick, R. and Reimer, C. W.: The diatoms of the United States.,Vol. 2, Monographs of the Academy of Natural Sciences of Philadelphia, Number 13, 1975

Plater, A. J., Boyle, J. F., Mayers, C., Turner, S. D., and Stroud, R. W.: Climate and human impact on lowland lake sedimentation in Central Coastal California: the record from ca. $650 \mathrm{AD}$ to the present, Reg. Environ. Change, 6, 71-85, 2006.

Reimer, P. J., Baillie, M. G. L., Bard, E., Bayliss, A., Beck, J. W., Blackwell, P. G., Bronk Ramsey, C., Buck, C. E., Burr, G. S., Edwards, R. L., Friedrich, M., Grootes, P. M., Guilderson, T. P., Hajdas, I., Heaton, T. J., Hogg, A. G., Hughen, K. A., Kaiser, K. F., Kromer, B., McCormac, F. G., Manning, S. W., Reimer, R. W., Richards, D. A., Southon, J. R., Talamo, S., Turney, C. S. M., van der Plicht, J., and Weyhenmeyer, C. E.: INTCAL09 and MARINE09 radiocarbon age calibration curves, 0-50,000 years cal BP, Radiocarbon, 51, 1111-1150, 2009.

Renberg, I.: A procedure for preparing large sets of diatom slides from sediment cores, J. Paleolimnol., 4, 87-90, 1990.

Robertshaw, P. and Taylor, D.: Climate change and the rise of political complexity in western Uganda, J. Afr. Hist., 4, 1-28, 2000.

Robertshaw, P., Taylor, D., Doyle, S., and Marchant, R.: Famine, climate and crisis in Western Uganda, in: Past climate variability through Europe and Africa, edited by: Battarbee, R. W., Gasse, F. and Stickley, C. E., Dordrecht, Springer, 638 pp., 2004.

Russell, J. M. and Johnson, T. C.: A high-resolution geochemical record from lake Edward, Uganda Congo and the timing and causes of tropical African drought during the late Holocene, Quat. Sci. Rev., 24, 1375-1389, 2005a.

Russell, J. M. and Johnson, T. C.: Late Holocene climate change in the North Atlantic and Equatorial Africa: millennial scale ITCZ migration, Geophys. Res. Lett., 32, L17705, doi:10.1029/2005GL023295, 2005b.

Russell, J. M. and Johnson, T. C.: Little Ice Age drought in equatorial Africa: Intertropical Convergence Zone migrations and El Niño-Southern Oscillation variability, Geol. Soc. Am., 35, $21-$ 24, 2007.

Russell, J. M., Eggermont, H., and Verschuren, D.: Spatial complexity during the Little Ice Age in tropical East Africa: sedimentary records from contrasting crater lake basins in western Uganda, Holocene, 17, 183-193, 2007.

Russell, J. M., McCoy, S. J., Verschuren, D., Bessems, I., and Huang, Y.: Human impacts, climate change, and aquatic ecosystem response during the past $2000 \mathrm{yr}$ at Lake Wandakara, Uganda, Quat. Res., 72, 315-324, 2009.

Ryves, D. B., Juggins, S., Fritz, S. C., and Battarbee, R. W.: Experimental diatom dissolution and the quantification of the microfossil preservation in sediments, Palaeogeogr. Palaeoclimatol. Palaeoecol., 172, 99-113, 2001.

Ryves, D. B., Mills, K., Bennike, O., Broderson, K. P., Lamb, A. L., Leng, M. J., Russell, J. M., and Ssemmanda, I.: Environmental change over the last millennium recorded in two contrasting crater lakes in western Uganda, eastern Africa (Lakes Kasenda and Wandakara), Quat. Sci. Rev., 30, 555-569, 2011.

Sabater, S.: Diatom communities as indicators of environmental stress in the Guadiamar River, S-W Spain, following a major mine tailings spill, J. Appl. Phycol., 12, 113-124, 2000.

Slota, P. J., Jull, A. J. T., Linick, T. W., and Toolin, L. J.: Preparation of small samples for ${ }^{14} \mathrm{C}$ accelerator targets by catalytic reduction of CO, Radiocarbon, 29, 303-306, 1987.

Ssemmanda, I., Ryves, D. B., Bennike, O., and Appleby, P. G.: Vegetation history in west Uganda during the last 1200 years: a sediment-based reconstruction from two crater lakes, Holocene, 15, 119-132, 2005.

Stager, J. C.: The diatom record of Lake Victoria (East Africa): The last 17,000 years, in: Proceedings of the Seventh International Diatom Symposium, edited by: Mann, D. G., Strauss and Cramer, Koenigstein, 1984.

Stager, J. C. and Johnson, T. C.: A $12,400{ }^{14} \mathrm{C}$ yr offshore diatom record from east central Lake Victoria, East Africa, J. Paleolimnol., 23, 373-383, 2007.

Stager, J. C., Cumming, B. F., and Meeker, L.: A high-resolution 11,400-yr diatom record from Lake Victoria, East Africa, Quat. Res., 47, 81-89, 1997.

Stager, J. C., Ryves, D., Cumming, B. F., Meeker, L. D., and Beer, J.: Solar variability and the levels of Lake Victoria, East Africa, during the last millennium, J. Paleolimnol., 33, 243-251, 2005.

Stager, J. C., Ruzmaikin, A., Conway, D., Verburg, P., and Mason, P. J.: Sunspots, El Niño, and the levels of Lake Victoria, East Africa, J. Geophys. Res., 112, D15106, doi:10.1029/2006JD008362, 2007.

Stuiver, M. and Braziunas, T. F. Atmospheric ${ }^{14} \mathrm{C}$ and century-scale solar oscillations, Nature, 338, 405-408, 1989.

Stuiver, M. and Reimer, P. J.: Extended ${ }^{14} \mathrm{C}$ database and revised CALIB radiocarbon calibration program, Radiocarbon, 35, 215 230, 1993. 
Taylor, D., Robertshaw, P., and Marchant, R. A.: Environmental change and political-economic upheaval in pre-colonial western Uganda, Holocene, 10, 527-536, 2000.

ter Braak, C. J. F. and Prentice, I. C.: A theory of gradient analysis, Adv. Ecol. Res., 18, 271-317, 1988.

ter Braak, C. J. F. and Šmilauer, P.: CANOCO reference manual and CanoDraw for Windows user's guide: software for canonical community ordination (version 4.5). Microcomputer Power, Ithaca, New York, 352 pp., 2002.

Tierney, J. E., Smerdon, J. E., Anchukaitis, K. J., and Seager, R.: Multidecadal variability in East African hydroclimate controlled by the Indian Ocean, Nature, 493, 389-392, 2013.

Tuchman, N. C., Schollett, M. A., Rier, S. T., and Geddes, P.: Differential heterotrophic utilization of organic compounds by diatoms and bacteria under light and dark conditions, Hydrobiologia, 561, 167-177, 2006.

Van Dam, H., Mertens, A., and Sinkeldam, J.: A coded checklist and ecological indicator values of freshwater diatoms from the Netherlands, Netherlands Journal of Aquatic Ecology, 28, 117 133, 1994.
Verschuren, D.: Reconstructing fluctuations of a shallow East African lake during the past 1800 years from sediment stratigraphy in a submerged crater basin, J. Paleolimnol., 25, 297-311, 2001.

Verschuren, D.: Decadal and century-scale climate variability in tropical Africa during the past 2000 years, in: Past climate variability through Europe and Africa, edited by: Battarbee, R. W. Gasse, F. and Stickley, C., Dordrecht, Springer, 2004.

Verschuren, D. and Charman, D.: Latitudinal linkages in lateHolocene moisture-balance variation, in: Natural climate variability and global warming: A Holocene perspective, edited by: Battarbee, R. W. and Binney, H. A., Oxfrod, Blackwell, 2008.

Verschuren, D., Laird, K. R., and Cumming, B. F.: Rainfall and drought in equatorial east Africa during the past 1,100 years, Nature, 403, 410-414, 2000.

Verschuren, D., Johnson, T. C., Kling, H. J., Edgington, D. N., Leavitt, P. R., Brown, E. T., Talbot, M. R., and Hecky, R. E.: History and timing of human impact on Lake Victoria, East Africa, Proc. R. Soc. Biol. Ser. B, 269, 289-294, 2002. 